\title{
Agromorphological Traits Variability of the Ethiopian Lentil and Exotic Genotypes
}

\author{
Fikru Mekonnen, ${ }^{1}$ Firew Mekbib, ${ }^{1}$ Shiv Kumar, ${ }^{2}$ Seid Ahmed, ${ }^{3}$ and Tilak R. Sharma ${ }^{4}$ \\ ${ }^{1}$ School of Plant Sciences, College of Agriculture and Environmental Sciences, Haramaya University, P.O. Box 138, Dire Dawa, Ethiopia \\ ${ }^{2}$ International Center for Agricultural Research in the Dry Areas (ICARDA), Tel Hadya, P.O. Box 5466 Aleppo, Syria \\ ${ }^{3}$ International Center for Agricultural Research in the Dry Areas (ICARDA), P.O. Box 5689, Addis Ababa, Ethiopia \\ ${ }^{4}$ Department of Agricultural Biotechnology, Chaudhary Sarwan Kumar Himachal Pradesh Agricultural University, \\ Palampur 176 062, India \\ Correspondence should be addressed to Fikru Mekonnen; tiewoast@gmail.com
}

Received 18 February 2014; Accepted 23 May 2014; Published 22 June 2014

Academic Editor: Ayman Suleiman

Copyright (C) 2014 Fikru Mekonnen et al. This is an open access article distributed under the Creative Commons Attribution License, which permits unrestricted use, distribution, and reproduction in any medium, provided the original work is properly cited.

\begin{abstract}
Understanding the genetic relationships and diversity of Ethiopian lentil in relation to lentil from other countries is important in attempting to widen the genetic base of germplasm in the country. The objectives of this study were to generate information on agromorphological variability, to estimate PCV, GCV, heritability, and expected genetic advance of quantitative traits of lentil. 228 genotypes with different population types were studied for 11 agromorphological traits and rust disease severity score for two seasons (2011-2012) over three locations. The analysis of variance showed highly significant variations $(P \leq 0.01)$ among genotypes for all characters studied. As per genetic parameter values, four groups of character were deduced. It is inferred that the exotic genotypes introduced from ICARDA showed rich genetic bases for 100-seed weight, number of seeds per plant, seed weight per plant, resistance source for rust, and high yielder in high yielding environment, where rainfall is not a major problem. Use the Ethiopian accessions for developing cultivars that could be used in double cropping and drought prone areas.
\end{abstract}

\section{Introduction}

Lentil (Lens culinaris Medik. subsp. culinaris) is a short, slender annual cool-season food legume. The center of origin of lentil is the Near East where it was first domesticated in the Fertile Crescent around 7000 BC [1]. According to Barulina [2], two varietal types based on seed size were recognized: the small-seeded microsperma and the macrosperma with relatively large flattened pods. The largest lentil producer is India, followed by Canada and Turkey, accounting for $68 \%$ of the global production [3]. In Africa, Ethiopia, Morocco, and Tunisia are the leading producers, but $61 \%$ of the areas and $68 \%$ of the production belong to Ethiopia [4]. Lentil is an important dietary source of macro- and micronutrients for both rural and urban dwellers. It provides sufficient amounts of the most essential amino acids to meet nutrient requirements. It is a cash crop fetching the highest price in domestic market compared to all other food legumes and major cereal crops [5]. Global, African, and Ethiopian lentil productivity is about $887 \mathrm{~kg} / \mathrm{ha}, 644 \mathrm{~kg} / \mathrm{ha}$ [3], and $1168 \mathrm{~kg} / \mathrm{ha}$, respectively [6]. Biotic and abiotic factors limit lentil productivity and seed quality. The major yield gap contributing factors are insect pests, diseases, low yielding landraces grown by farmers, and the narrow genetic base $[7,8]$.

Prior knowledge of genetic variability and characterization of genetic resources within the germplasm available at a gene bank has an important implication for future utilization and collection activities, to identify areas of major priority for conservation and improvement programs [9]. Quantitative traits provide an estimate of genetic diversity, and various numerical taxonomic techniques have been successfully used to classify and measure the pattern of genetic diversity in germplasm, as in lentil $[10,11]$. Morphological characterization is the first step in the classification and description of any crop germplasm [12]. The assessment of 
TABle 1: Geographical, climatic, and soil features of the experimental sites.

\begin{tabular}{lccc}
\hline Agroecological & Sirinka & Sinana & Chefe Donsa \\
\hline Range of temperature $\left({ }^{\circ} \mathrm{C}\right)$ & $21-32$ & $9.3-20.9$ & $8.9-28.3$ \\
Mean annual rainfall $(\mathrm{mm})$ & 876 & 808 & 851 \\
Altitude $(\mathrm{masl})$ & 1850 & 2450 & 1900 \\
Latitude & $12^{\circ} .11^{\prime} \mathrm{N}$ & $7^{\circ} 7^{\prime} \mathrm{N}$ & $8^{\circ} 44^{\prime} \mathrm{N}$ \\
Longitude & $39^{\circ} 62^{\prime} \mathrm{E}$ & $40^{\circ} 10^{\prime} \mathrm{E}$ & $39^{\circ} 95^{\prime} \mathrm{E}$ \\
Soil texture & Clay soil & Clay soil & Light soil \\
Soil type & Eutric vertisol black soil & Pellic vertisol slightly acidic & Afisols and vertisol black soil \\
\hline
\end{tabular}

genetic variability present in a given crop population can be determined by using the biometrical components such as range, variance, coefficient of variation, standard error, and heritability. The relative magnitude of these components determines the genetic properties of the population, in particular, the degree of resemblance between germplasm, that is, various determinants of the phenotype [13]. Reference [14] emphasized that the uses of the genetic coefficient of variability together with heritability and genetic advance values would determine the best picture of the amount of progress to be expected from a selection and determine the selection method to improve a character.

Several researchers investigated the diversity of economically important traits of lentil germplasm and found considerable variations $[10,11,15-20]$. Some quantitative evaluations of the Ethiopian landraces revealed potential variability for morphological traits $[5,7,8,21-25]$. Understanding the genetic relationships and diversity of the Ethiopian lentil in relation to the germplasm from other countries is important to widen the genetic base of a germplasm. However, information is not exhaustive for different population structures of local and exotic genotypes on the genetic variability of important traits, which have economic benefit. Hence, the objectives of this study were to generate information on morphological variability and to estimate the phenotypic coefficient of variation, the genetic coefficient of variation, the heritability, and genetic advance of quantitative traits in lentil.

\section{Materials and Methods}

2.1. Description of the Study Sites. The field experiments were conducted on a hot spot area for rust. The areas included Sirinka Agricultural Research Center (SIARC) in the northeastern part of Ethiopia for two seasons (2011 and 2012), Chefe Donsa in the central part of Ethiopia, and Sinana Agricultural Research Center (SARC) in southeastern part of Ethiopia during the 2011/12 cropping season (Table 1 and Figure 1).

2.2. Plant Materials. Out of the 228 genotypes considered for this study, 158 were planted for morphological evaluation at SRARC in the 2010/2011 cropping season. Of these, 104 genotypes were from the Ethiopian lentil gene pool collected from six major lentil production regions (Figure 2) and were kept by the Institute of Biodiversity Conservation (IBC).

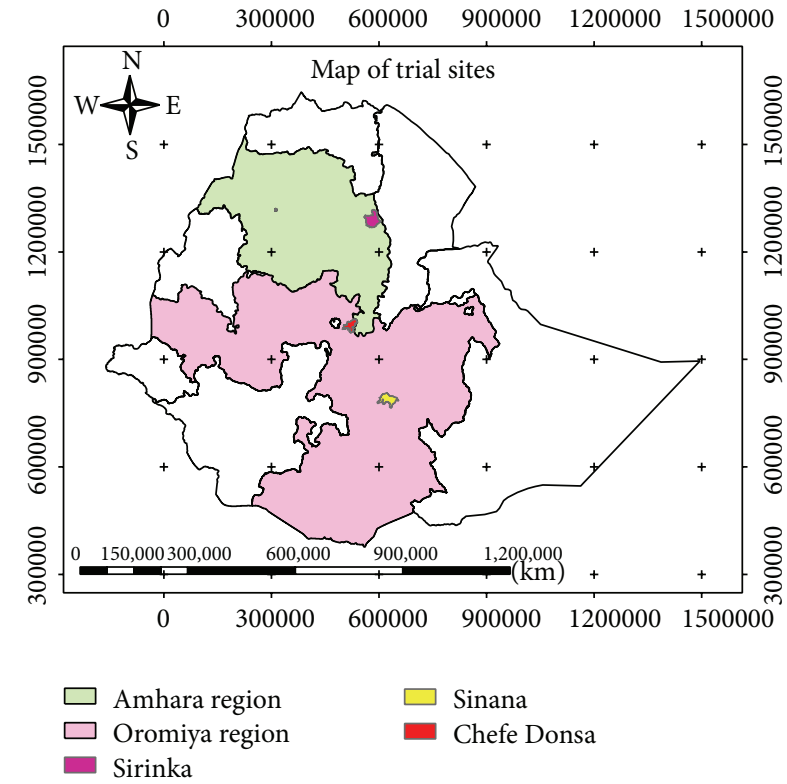

FIGURE 1: Geographical position of the experimental sites.

The accessions represent over $17 \%$ of the 618 lentil accession holdings of IBC. Rust susceptible check/EL-142/and wilt susceptible check/ILL-590/NEL 590/, as well as six commercial national released varieties (Alemaya, Adaa, Teshale, Alem Tena, Chekol and Derash), were used as a check. Ten elite breeding lines from the DebreZeit Agricultural Research Station (DZARC), Ethiopia, were included. Thirty-six parental lines and elite lines based on superiority for agronomic traits introduced from the International Center for Agricultural Research in Dry Areas (ICARDA) were included (Table 2). In the 2011/12 cropping season, 228 genotypes plus RILs were included in the study across three locations: Sirinka, Chefe Donsa, and Sinana.

2.3. Experimental Layout and Design. A randomized complete block design (RCBD) was used with three replications, in the 2010/2011 cropping season at SIARC. A unit plot comprised 2-meter length row with a plot size of $\left(0.8 \mathrm{~m}^{2}\right)$. Row-to row distance was $20 \mathrm{~cm}$. The distance between two plots was $50 \mathrm{~cm}$ and the distance between two blocks was $100 \mathrm{~cm}$. The genotypes were planted in the first week of July. In the 2011/12 cropping season, the experiment was carried out 
TABLE 2: List of genotypes and their origin.

\begin{tabular}{|c|c|c|c|}
\hline $\begin{array}{l}\text { Source of } \\
\text { origin }\end{array}$ & $\begin{array}{c}\text { Number of } \\
\text { genotypes }\end{array}$ & Name of genotype & $\begin{array}{c}\text { Type of } \\
\text { genotypes }\end{array}$ \\
\hline Tigray & 8 & $\begin{array}{l}\text { Acc. no. } 219957,235383,237503,237504,241785,242604, \\
243447\end{array}$ & Landrace \\
\hline Amhara & 54 & $\begin{array}{l}\text { Acc. no. } 36003,36025,36028,36039,36041,36061,36071, \\
36085,36088,36089,36097,36103,36104,36105,36137,36139, \\
36150,36162,36165,36168,207258,207274,207287,207309, \\
212745,215248,215249,223221,228242,229179,229182, \\
229183,231247,235013,235015,235016,235017,236484, \\
236486,236487,237502,238978,238979,241784,241786, \\
243433,243436,243440,243443,244606,244610,244615, \\
244619,244623\end{array}$ & Landrace \\
\hline Oromya & 29 & $\begin{array}{l}\text { Acc. no. } 36001,36007,36009,36013,36015,36019,36023 \text {, } \\
\text { 36029, 36033, 36042, 36048, 36058, 36110, 36120, 36131, } \\
\text { 203141, 215806, 216877, 228809, 230521, 230833, 230834, } \\
230837,231248,235698,236438,236892,237027,238971\end{array}$ & Landrace \\
\hline SNNP & 2 & Acc. no. 36147 and Acc. No., 228243 & Landrace \\
\hline Somali & 1 & Acc. no. 230832 & Landrace \\
\hline DZARC & 6 & $\begin{array}{l}\text { /ILL4225 x ILL4605/ /ILL 6821/ Alemaya, /ILL } 1 \text { x ILL } \\
\text { 1169//ILL 6027/ ADAA, /ILL 7978/ Teshale, /Alemaya x } \\
\text { FLIP88-41L/ Derash, /ILL 7981/ Aleme Tena and P160/ILL } \\
\text { 2704/ /Chekol/ }\end{array}$ & $\begin{array}{l}\text { Improved } \\
\text { variety }\end{array}$ \\
\hline Unknown & 10 & $\begin{array}{l}\text { Acc. no. } 36134,207260,211062,211078,211110,220120,211131, \\
\text { 233349, } 233973,241782\end{array}$ & Landrace \\
\hline ICARDA & 22 & $\begin{array}{l}\text { L-9-11, X2002S 219 /ILL 6821/, X2002S } 221 \text { /7980/, X2002S } \\
\text { 221/FLIP 96-47 L//7979/, X2003S 195/ILL 7115/, /ILL4965 x } \\
\text { ILL6155/FLIP-97-16L/ILL 8078/, /ILL 883 x ILL } \\
\text { 470/FLIP-84-95L/ILL 5722/, X2003S 233/ILL 8009/, 2003S } \\
\text { 235, X2003S 238 /ILL 4605/, X2005S 215/ILL 6002/, 2006S } \\
\text { 122 /FLIP 2003-43L/ /ILL 7010 x ILL 1939/ /ILL 9932/, /ILL } \\
2573 \times \text { ILL 7537/ /FLIP 2003-62 L/ /ILL 9951/X2006S 122, } \\
\text { /ILL 7620 x ILL 9151/ /FLIP 2003-56L/ /ILL 9945/X2006S 127, } \\
\text { X2006S 129/F2/, X2006S 130/FLIP 93-46L/ /ILL 547/, } \\
\text { X2006S 130/FLIP 96-46 L//ILL 7978/, X2006S } \\
\text { 133/FLIP87-21L/ /ILL 4349 x ILL4605//ILL 6211/, X2006S } \\
\text { 134/ILL8174/, X2002S 219/shehor-74/ /ILL 7554/, X2003S } \\
\text { 222/ILL 213/, X2006S 128/ILL 5480/ }\end{array}$ & Parent \\
\hline DARC & 11 & $\begin{array}{l}\text { EL-142/ILL 5071/, 87S-93549XEL-1O3-3, 87s-93549XEL-03-4, } \\
\text { Chekol X R-186-1, Chekol x R-186-2, EL-142 X R-186-3, } \\
\text { EXOTIC \#DZ/2008 AK, Chekol x R-186-8-0, ILL-358 X } \\
\text { ILL-2573-2-2000, R-186X FLIP-86-38L, } \\
\text { R-186XFLIP-86-38L-23 }\end{array}$ & Breeding line \\
\hline ICARDA & 15 & $\begin{array}{l}\text { ILL-28501, FLIP-04-26L, FLIP-2004-37L, FLIP-2004-7L, } \\
\text { FLIP-2006-20L, FLIP-2006-60L, FLIP-87-68L, FLIP-93-63L, } \\
\text { FLIP-97-61L, FLIP-97-68L, /ILL 6037 x ILX 87062/ } \\
\text { FLIP2005-24L/ ILL-10045, ILL-10680, ILL-590/NEL 590/, } \\
\text { L-830, Precoze/ILL 4605/ }\end{array}$ & Breeding line \\
\hline ICARDA & 70 & RIL1-RIL 70 & RIL \\
\hline
\end{tabular}

Genotypes represent different population groups of lentil germplasm such as landrace, elite breeding lines, putative parents, and recombinant inbred lines (RIL). Unknown $=$ originated from Ethiopia but sites of collection are not mentioned .

$\mathrm{RIL}=$ recombinant inbred line.

using the augmented design with a single row of $2 \mathrm{~m}$ length for each genotype planted in five blocks. Eight checks were replicated within each block. Planting was done in the first week of July at SIARC, in mid-August at Chefe Donsa and in mid-September at SARC. The recommended agronomic packages were applied for raising a successful crop.
2.4. Data Collection. Data were recorded on 10 randomly selected plants on plant basis for plant height $(\mathrm{PH})$, number of pods/plant (NP), number of seeds/pod (NS), number of seeds/plant (NSPP), and seed weight/plant (SWPP), whereas days to flowering (DFF), days to maturity (DM), above ground biomass (BI), 100-seed weight in gram (SW), seed 
TABLE 3: Mean squares for agromorphological traits of 158 lentil genotypes at Sirinka in the 2010/11 cropping season.

\begin{tabular}{|c|c|c|c|c|c|c|c|c|c|c|c|c|}
\hline \multirow{2}{*}{ Sources of variation } & \multirow{2}{*}{$\mathrm{df}$} & \multicolumn{11}{|c|}{ Mean squares } \\
\hline & & DFF & DM & NP & NS & SWPP & NSPP & $\mathrm{PH}$ & SW & BI & SY & PSS \\
\hline Replication & 2 & 561.9 & 1248.1 & 3067.3 & 1.27 & 2.1 & 8980.1 & 379.2 & 0.01 & 6475 & 46675.2 & 0.2 \\
\hline Genotype & 157 & $70.6^{* *}$ & $408.3^{* *}$ & $359.7^{* *}$ & $0.3^{* *}$ & $0.7^{* *}$ & $859.2^{* *}$ & $48.7^{* *}$ & $0.99^{* *}$ & $35878^{* *}$ & $4645.4^{* *}$ & $1.8^{* *}$ \\
\hline Error & 314 & 13.9 & 45.47 & 126.3 & 0.06 & 0.17 & 200.3 & 8.13 & 0.1 & 6140 & 994 & 0.2 \\
\hline CV\% & & 6.5 & 7 & 31.9 & 19.9 & 36.8 & 33 & 8.2 & 12.2 & 27.3 & 37.1 & 9.7 \\
\hline Mean & & 57.2 & 95.7 & 35.3 & 1.2 & 1.1 & 42.9 & 34.6 & 2.5 & 286.8 & 84.9 & 5 \\
\hline LSD (at 5\%) & & 6 & 11.1 & 30.5 & 0.4 & 0.6 & 23.4 & 0.5 & 4.6 & 112.7 & 47.9 & 0.8 \\
\hline
\end{tabular}

$\mathrm{df}=$ Degree of Freedom

$\mathrm{DF}=$ days to $50 \%$ flowering, $\mathrm{DM}=$ days to $90 \%$ maturity, $\mathrm{NP}=$ number of pods per plant, NS = number of seeds per pod, SWPP = Seed Weight per Plant, $\mathrm{NSPP}=$ Number of Seeds per Plant, $\mathrm{PH}=$ Plant height in $\mathrm{cm}, \mathrm{SW}=100$-seed weight in gram, BI = Bio mass, PSS $=$ Pod set Score

${ }^{* *},{ }^{*}=$ Significant at $5 \%$ and $1 \%$ probability levels, respectively.

$33^{\circ} 0^{\prime} 0^{\prime \prime} \mathrm{E} \quad 36^{\circ} 0^{\prime} 0^{\prime \prime} \mathrm{E} \quad 39^{\circ} 0^{\prime} 0^{\prime \prime} \mathrm{E} \quad 42^{\circ} 0^{\prime} 0^{\prime \prime} \mathrm{E} \quad 45^{\circ} 0^{\prime} 0^{\prime \prime} \mathrm{E} \quad 48^{\circ} 0^{\prime} 0^{\prime \prime} \mathrm{E}$

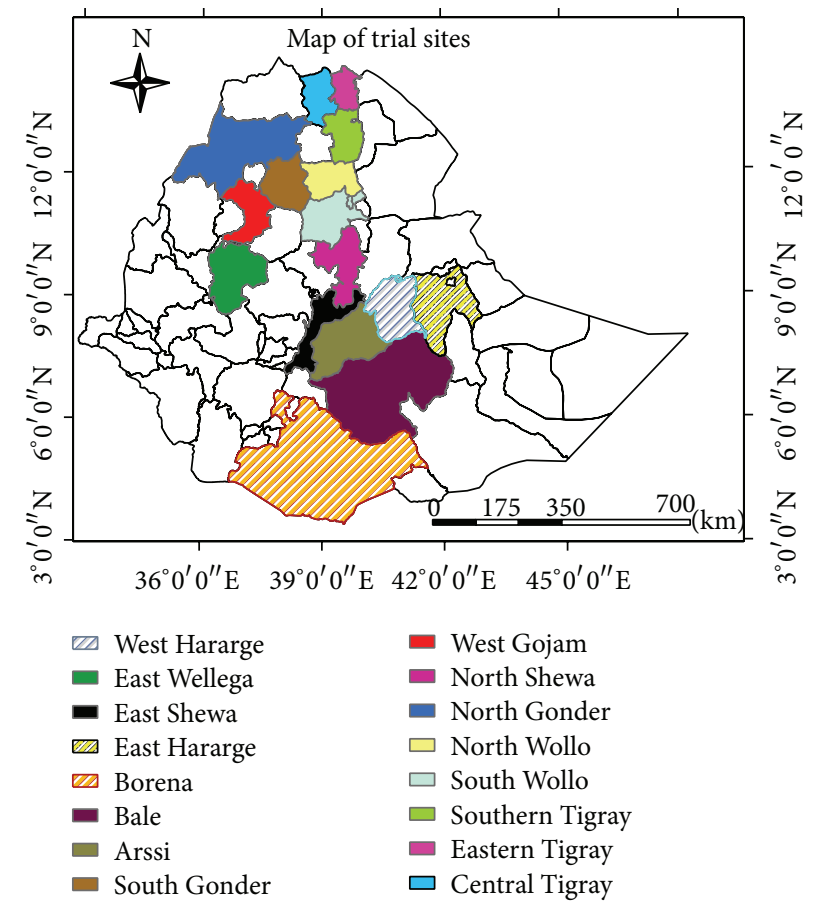

FIGURE 2: Map of Ethiopia showing areas of collection sites (shaded region) of the landrace accessions.

yield/plant (SY), pod set score (PSS) (1-9 rating scale where $1=$ very poor pod setting and $9=$ excellent pod setting), and rust severity scored on a 1-9 scale (1-9 rating scale where $1=$ highly resistant and 9 = highly susceptible) before flowering (RSBF) and after flowering (RSAF) were recorded on plot basis according to [26].

2.5. Data Analysis. Plot mean values were calculated for all traits and used for the analysis of variance (ANOVA). The estimation of genetic parameters was analyzed using GenStat Release 13.3. [27]. Phenotypic and genotypic variances for the augmented design were computed for all traits based on the methods of [28]. The pooled analysis for augmented design was carried out according to $[29,30]$ using GenStat Release
15.1 [31]. The broad sense of heritability $\left(h^{2}\right)$ was estimated using the genotype mean according to [14]. Consider

$$
h^{2}=\left[\frac{\sigma^{2} g}{\sigma^{2} p}\right] \times 100 .
$$

Genetic advance (GA) for selection intensity $(K)$ at $5 \%$ is estimated according to [14] using the formula: GA = $(K)(\sigma p)\left(h^{2}\right)$

The genetic advance as the percentage of the mean (GAM) was estimated as per [32] formula: $\mathrm{GAM}=(\mathrm{GA} / \bar{X}) *$ 100 .

\section{Results}

3.1. Analysis of Variance. Highly significant genotypic $(P \leq$ 0.01 ) differences were observed for all parameters measured in the 2010/11 cropping season at Sirinka indicating that the variation was genetic. The mean square, $\mathrm{CV}$, and mean values for traits of the genotype were presented in Table 3.

Moderate variabilities with an intermediate coefficient of variation $(\mathrm{CV})$ among the genotypes were observed for days to $50 \%$ flowering, days to $90 \%$ maturity, plant height, and pod set score, whereas considerable variations were observed for the rest of the traits among the genotypes (Table 3 ).

The analysis of variance for the 2011/12 cropping season within the check showed significant variation at Sirinka, except for two traits: number of seeds/pods and number of seeds/plant (Table 4). At Chefe Donsa, days to 50\% flowering, number of pods/plant, number of seeds/pods, number of seeds/plant, and seed weight/plant had nonsignificant variation within the checks (Table 5). At Sinana, all traits showed significant variability, except days to $50 \%$ flowering, days to $90 \%$ maturity, number of seeds/pods, and above ground biomass within the checks (Table 6). Consistent significant variations were noted across locations within the checks for plant height, 100-seed weight, and seed yield (Tables 4, 5, and 6).

The analysis of variance showed a highly significant variation $(P \leq 0.01)$ for days to $50 \%$ flowering, days to $90 \%$ maturity, number of pods/plant, and number of seeds/pods within the test genotypes at Sirinka (Table 4). At Chefe Donsa, analysis depicted a highly significant variation 
TABLE 4: Mean squares for agromorphological traits of 228 lentil genotypes at Sirinka in the 2011/12 cropping season.

\begin{tabular}{|c|c|c|c|c|c|c|c|c|c|c|c|}
\hline \multirow{2}{*}{ Sources of Variation } & \multirow{2}{*}{$\mathrm{df}$} & \multicolumn{10}{|c|}{ Mean squares } \\
\hline & & DFF & $\mathrm{DM}$ & NP & NS & NSPP & SWPP & $\mathrm{PH}$ & SW & $\mathrm{BI}$ & SY \\
\hline Block & 4 & $413.4^{* *}$ & $350.5^{* *}$ & $983.2^{*}$ & $0.21^{* *}$ & $1693.6^{*}$ & 1.16 & $35.49^{*}$ & $0.8^{*}$ & $113623^{* *}$ & 8974 \\
\hline Within checks & 7 & $155.5^{* *}$ & $504.6^{* *}$ & $734.6^{*}$ & 0.1 & 1213.8 & $1.9^{*}$ & $37.3^{*}$ & $2.3^{* *}$ & $67151^{*}$ & $9542^{*}$ \\
\hline Within test genotypes & 219 & $91.9^{* *}$ & $182.5^{* *}$ & $1053.4^{* *}$ & $0.2^{* *}$ & 722.7 & 0.5 & $243.0^{*}$ & $0.5^{*}$ & 18463 & 2807 \\
\hline Between check and test genotypes & 1 & 0.6 & 35.2 & 995.1 & $0.3^{* *}$ & $5227.6^{* *}$ & $13.2^{* *}$ & 18.2 & $4.6^{* *}$ & $437621^{* *}$ & $110311^{* *}$ \\
\hline Residual & 35 & 14.1 & 34.1 & 302 & 0.04 & 546.1 & 0.7 & 13.5 & 0.3 & 24236 & 3801 \\
\hline
\end{tabular}

$\mathrm{df}=$ degree of freedom.

$\mathrm{DFF}=$ days to $50 \%$ flowering, $\mathrm{DM}=$ days to $90 \%$ maturity, $\mathrm{NP}=$ number of pods per plant, $\mathrm{NS}=$ number of seeds per pod, SWPP = seed weight per plant, $\mathrm{NSPP}=$ number of seeds per plant, $\mathrm{PH}=$ plant height in $\mathrm{cm}, \mathrm{SW}=100$-seed weight in gram, $\mathrm{BI}=$ biomass, $\mathrm{PSS}=$ pod set score.

${ }^{* *},{ }^{*}=$ significant at $5 \%$ and $1 \%$ probability levels, respectively.

TABle 5: Mean squares for agromorphological traits of 228 lentil genotypes at Chefe Donsa in the 2011/12 cropping season.

\begin{tabular}{|c|c|c|c|c|c|c|c|c|c|c|c|c|}
\hline \multirow{2}{*}{ Sources of variation } & \multirow{2}{*}{$\mathrm{df}$} & \multicolumn{11}{|c|}{ Mean squares } \\
\hline & & DFF & $\mathrm{DM}$ & NP & NS & NSPP & SWPP & $\mathrm{PH}$ & SW & BI & SY & RSAF \\
\hline Block & 4 & 24.4 & $327.9^{* *}$ & $664.7^{*}$ & 0.03 & $1489.4^{*}$ & $1.4^{*}$ & $12.6^{*}$ & $0.7^{* *}$ & $77552^{* *}$ & $3332^{*}$ & $10.3^{* *}$ \\
\hline Within check & 7 & 12.6 & $223.6^{*}$ & 51.6 & 0.04 & 292.6 & 0.4 & $22.0^{* *}$ & $1.2^{* *}$ & $23490^{*}$ & $3363^{*}$ & $17.2^{* *}$ \\
\hline Within test genotypes & 219 & $30.4^{* *}$ & 133.3 & 184.3 & 0.06 & 495.7 & 0.3 & $15.0^{* *}$ & $0.6^{* *}$ & 8941 & 1314 & $4.8^{* *}$ \\
\hline Between check and test genotypes & 1 & $101.5^{* *}$ & 105 & $988.5^{*}$ & 0.1 & 1127.8 & $2.3^{*}$ & 7.7 & 0.03 & $227174^{* *}$ & $41227^{* *}$ & $27.3^{* *}$ \\
\hline Residual & 35 & 12.1 & 83.4 & 188.2 & 0.06 & 560.1 & 0.4 & 4.5 & 0.1 & 10084 & 1183 & 2 \\
\hline
\end{tabular}

${ }^{* *},{ }^{*}=$ significant at $5 \%$ and $1 \%$ probability levels, respectively.

TABLE 6: Mean squares for agromorphological traits of 228 lentil genotypes at Sinana in the 2011/12 cropping season.

\begin{tabular}{|c|c|c|c|c|c|c|c|c|c|c|c|c|}
\hline \multirow{2}{*}{ Sources of vriation } & \multirow{2}{*}{$\mathrm{df}$} & \multicolumn{11}{|c|}{ Mean squares } \\
\hline & & DFF & $\mathrm{DM}$ & NP & NS & NSPP & $\mathrm{PH}$ & SW & BI & SY & RSBF & RSAF \\
\hline Block & 4 & $305.8^{* *}$ & $2224^{*}$ & 50.9 & 0.04 & $319.6^{*}$ & $147.8^{* *}$ & $1.3^{* *}$ & $153488^{* *}$ & $6897.6^{* *}$ & $5.1^{* *}$ & $16.1^{* *}$ \\
\hline Within check & 7 & 224.2 & 2473.1 & $76.5^{* *}$ & 0.1 & $274.5^{*}$ & $53.7^{*}$ & $2.6^{* *}$ & 30505 & $6842.8^{* *}$ & $1.7^{*}$ & 5.9 \\
\hline Within test genotypes & 219 & $10054.6^{* *}$ & 36536 & $65.6^{* *}$ & $0.1^{*}$ & $256.2^{* *}$ & 29.3 & $0.7^{* *}$ & 34051 & $1279.1^{*}$ & $2.0^{* *}$ & 4.6 \\
\hline Between check and test genotypes & 1 & 0.05 & 121.1 & $124.6^{*}$ & 0.2 & 345.1 & $184.9^{* *}$ & $3.0^{* *}$ & $474202^{* *}$ & $80244.5^{* *}$ & $10.8^{* *}$ & $69.1^{* *}$ \\
\hline Residual & 35 & 19.1 & 244.6 & 30 & 0.1 & 116.5 & 23 & 0.1 & 29335 & 823.2 & 0.8 & 3.8 \\
\hline
\end{tabular}

RSBF; Rust disease severity score before flowering.

RSAF; Rust disease severity score after flowering.

${ }^{* *},{ }^{*}=$ significant at $5 \%$ and $1 \%$ probability levels, respectively.

$(P \leq 0.01)$ within test genotypes for days to $50 \%$ flowering, plant height, 100-seed weight, and rust disease severity score after flowering (Table 5), whereas at Sinana all traits revealed significant variation $(P \leq 0.05)$ except days to $90 \%$ maturity, plant height, above ground biomass, and rust disease severity score after flowering within test genotypes (Table 6).

The analysis of variance between check and test genotypes for the 2011/12 cropping season showed highly significant differences except for days to $50 \%$ flowering, days to $90 \%$ maturity, number of pods/plant, and plant height at Sirinka (Table 4). At Chefe Donsa, significant $(P \leq 0.05)$ variations were observed for days to $50 \%$ flowering, number of pods/plant, seed weight/plant, above ground biomass, seed yield, and rust disease severity score between checks and test genotypes (Table 5), whereas, at Sinana, significant variations were recorded between checks and test genotypes for number of pods/plant, plant height, 100-seed weight, seed yield, and rust severity score before and after flowering (Table 6). The test for homogeneity of error variance was significant across locations because the genotypes perform differently across the three locations for yield and yield component traits. Thus, it could not make further valid inferences for the pooled ANOVA (Table 7). Besides, rust infection was severe at Sinana, mild at Chefe Donsa, and absent at Sirinka and then no combined analysis was made for this character.

The minimum and maximum values of 11 agromorphological traits analyzed for the 2010/2011 cropping season at Sirinka were presented in (Table 8). The range for days to $50 \%$ flowering was recorded from 42 to 78 days for Acc. number 36120 and breeding line (FLIP-04-26L), respectively (Table 12). The shortest maturity period was recorded (77 days) for Acc. number 36025 and the longest (138 days) for FLIP-04-26L. Parent X2003S 223 produced the minimum (1.6) number of pods/plant while the maximum (73.3 pods/plant) was noted for breeding line (R-186XFLIP-86$38 \mathrm{~L}-24)$. The shortest plant height of $20.6 \mathrm{~cm}$ was recorded for breeding line (FLIP-97-61L) and the highest was $44.7 \mathrm{~cm}$ for Acc. number 36001 . The minimum number of seeds/pod was 
TABLE 7: Mean squares of the combined analysis of variance for lentil yield and yield component traits and mean values for each location in the 2011/12 cropping season.

\begin{tabular}{lcccccccccc}
\hline Sources of variation & df & DFF & DM & NP & NS & NSPP & PH & SW & BI & SY \\
\hline Environment mean squares & 2 & $754.0^{* *}$ & $1065.0^{* *}$ & $557.9^{* *}$ & $17188.6^{* *}$ & $162.1^{* *}$ & $2028.3^{* *}$ & $153.2^{* *}$ & $1031.6^{* *}$ & $343.1^{* *}$ \\
Genotype mean squares & 227 & $3.6^{* *}$ & $1.2^{\mathrm{NS}}$ & $0.4^{\mathrm{NS}}$ & $0.01^{\mathrm{NS}}$ & $0.2^{\mathrm{NS}}$ & $0.9^{* *}$ & $8.9^{* *}$ & $0.4^{* *}$ & $1.1^{* *}$ \\
Residual mean squares & 454 & 1.5 & 1.61 & 1.6 & 0.9 & 0.7 & 0.4 & 1.7 & 0.2 & 0.5 \\
Range & & $41-91$ & $60-131$ & $12.1-298$ & $0.4-2.6$ & $20.6-64.3$ & $22.7-47$ & $0.8-5.1$ & $204.5-632$ & $19.8-172$ \\
Sirinka mean & & 56.4 & 91.4 & 37.4 & 1.2 & 43.77 & 33.9 & 2.7 & 269.8 & 83.2 \\
Chefe Donsa mean & & 56.1 & 114.5 & 29 & 1.5 & 43.8 & 27.71 & 2.8 & 269.4 & 86.8 \\
Sinana mean & & 66.3 & 104.6 & 19.2 & 1.9 & 34 & 40.5 & 2.4 & 521.3 & 44 \\
Environment mean & & 64 & 105 & 30 & 1.6 & 40 & 36 & 2.5 & 400 & 60 \\
\hline
\end{tabular}

$\mathrm{df}=$ degree of freedom.

$\mathrm{DFF}=$ days to $50 \%$ flowering, $\mathrm{DM}=$ days to $90 \%$ maturity, $\mathrm{NP}=$ number of pods per plant, NS = number of seeds per pod, SWPP $=$ seed weight per plant, $\mathrm{NSPP}=$ number of seeds per plant, $\mathrm{PH}=$ plant height in $\mathrm{cm}, \mathrm{SW}=100$-seed weight in gram, $\mathrm{BI}=$ biomass, $\mathrm{PSS}=$ pod set $\mathrm{score}$.

${ }^{* *},{ }^{*}=$ significant at $5 \%$ and $1 \%$ probability levels, respectively.

NS = nonsignificant.

TABLE 8: Genetic parameter estimates for agromorphological characters of lentil genotypes at Sirinka 2010/11 cropping season.

\begin{tabular}{lccccccccc}
\hline Traits & Mean & Range & GV & PV & PCV & GCV & $h^{2}$ & GA & GAM \\
\hline DFF & 57.2 & $42-78$ & 18.7 & 32.5 & 7.6 & 10 & 57.3 & 6.8 & 11.8 \\
DM & 95.7 & $77-138$ & 119.3 & 164.8 & 11.5 & 13.5 & 72.4 & 19.2 & 20.1 \\
NP & 35.3 & $1.6-73.3$ & 76.4 & 202.9 & 25 & 40.5 & 37.7 & 11.1 & 31.5 \\
NS & 1.2 & $0.5-2.0$ & 0.1 & 0.18 & 22.6 & 30.1 & 56 & 0.4 & 34.8 \\
PWPP & 1.5 & $0.24-8.1$ & 0.7 & 0.8 & 58.4 & 60.7 & 92.6 & 1.7 & 15.8 \\
SWPP & 1.1 & $0.1-3.4$ & 0.2 & 0.3 & 36.3 & 51.6 & 48.9 & 0.6 & 52 \\
NSPP & 42.9 & $5.5-103.1$ & 215.4 & 416.2 & 34.6 & 47.8 & 51.8 & 21.9 & 51 \\
PH & 34.6 & $20.6-44.7$ & 13.4 & 21.6 & 10.6 & 13.4 & 62.3 & 6 \\
SW & 2.5 & $1.38-4.9$ & 0.3 & 0.4 & 21.7 & 24.9 & 75.8 & 1 \\
BI & 286.8 & $35-767.8$ & 9806.7 & 15955 & 34.7 & 44.2 & 61.5 & 160.5 \\
SY & 84.9 & $0-347.2$ & 1192.3 & 2188.7 & 41.1 & 55.4 & 54.5 & 52.8 & 56.9 \\
PSS & 5 & $2-7$ & 0.5 & 0.7 & 14 & 17.1 & 66 & 62.2 \\
\hline
\end{tabular}

Triats, DFF = days to $50 \%$ flowering, $\mathrm{DM}=$ days to $90 \%$ maturity, $\mathrm{NP}=$ number of pods per plant, $\mathrm{NS}=$ number of seeds per pod, NSPP $=$ number of seeds per plant, $\mathrm{PH}=$ plant height in $\mathrm{cm}, \mathrm{SW}=100$-seed weight in gram, $\mathrm{BI}=$ above ground biomass, $\mathrm{SY}=$ seed yield .

$\mathrm{GV}=$ genotypic variance, $\mathrm{PV}=$ phenotypic variance, GCV = genetic coefficient of variation, $\mathrm{PCV}=$ phenotypic coefficient of variation, $h^{2}=$ broad sense of heritability, GA = genetic advance, GAM = genetic advance as the percentage of the mean.

recorded (0.5 seed) for landrace (Acc. number 36098) and the maximum (2 seeds) for parent line (X2003S 233/8009/). Seed weight/plant ranged from $0.1 \mathrm{~g}$ for parent line X2002S 219/shehor-74/7554 to $3.4 \mathrm{~g}$ for breeding line R-186XFLIP-8638L-24 (Table 12). The number of seeds/plant ranged from 5.5 for landrace (Acc. number 36098) to 103.1 for lines R186XFLIP-86-38L-24. The largest seed size was observed for parent line FLIP-2004-7L (4.9 g) while the parent line $\mathrm{X} 2003 \mathrm{~S} 233 / 8009 / \mathrm{had}$ a minimum seed weight of $1.4 \mathrm{~g}$. The lowest biomass/plant was recorded for the parent line X2003S 223 (35 g), and the highest biomass/plant was recorded for the parent line X2006S 128/5480/(767.8 g). The lowest seed yield $(0 \mathrm{~g})$ was recorded for landrace X2003S 223 whereas breeding line ILL-590 showed the highest seed yield (347.2 g) (Table 12).

3.2. Phenotypic and Genotypic Coefficients of Variation. Though variability in population is an indispensable prerequisite for any improvement, it is not the only criterion for deciding as to which trait is showing the highest degree of variability. Phenotype coefficient of variation (PCV) and genotype coefficient of variation (GCV) can help in this regard. Estimates of genetic parameter are shown in Tables $8,9,10$, and 11. PCV and GCV values of approximately more than $20 \%$ are regarded as high, whereas values less than $10 \%$ are considered low and values in between are considered as medium [33]. Based on this delineation, high PCV and GCV values were recorded for number of pods/plant, number of seeds/pod, pod weight/plant, seed weight/plant, number of seeds/plant, 100 seed weight, above ground biomass, and seed yield. However, days to $50 \%$ flowering, days to $90 \%$ maturity, and plant height showed lower GCV and PCV values in the 2010/2011 cropping season. In the 2011/12 cropping season, similar GCV and PCV patterns were recorded across the three locations for number of pods/plant, seed weight/plant, number of seeds/plant, above ground biomass, seed yield, and rust disease score, whereas low PCV and GCV were noted for number of pods/plant, number of seeds/pods, seed weight/plant, and number of seeds/plant at Chefe Donsa. 
TABLE 9: Genetic parameter estimates for agromorphological characters of lentil genotypes at Sirinka 2011/12 cropping season.

\begin{tabular}{lcccccccccc}
\hline Traits & Test genotype mean & Check mean & Grand mean & GV & PV & PCV & GCV & $h^{2}$ & GA & GAM \\
\hline DFF & 56.3 & 56.3 & 56.3 & 77.4 & 93 & 15.6 & 17.1 & 83.3 & 16.6 & 29.4 \\
DM & 91.7 & 91.2 & 91.7 & 145.2 & 182 & 13.1 & 14.7 & 79.8 & 22.2 & 24.2 \\
NP & 35.7 & 45.2 & 35.7 & 714.7 & 1025.1 & 75 & 89.8 & 69.7 & 45.9 & 128.8 \\
NS & 1.2 & 1.3 & 1.2 & 0.1 & 0.2 & 27.6 & 34.3 & 65 & 0.6 & 49.9 \\
NSPP & 40.7 & 59.6 & 40.7 & 146.4 & 176.8 & 32.7 & 32.7 & 82.8 & 22.7 & 55.7 \\
SW & 2.7 & 3.1 & 2.7 & 0.2 & 0.5 & 18.6 & 27.6 & 45.6 & 0.7 & 24.6 \\
PH & 33.5 & 35.2 & 33.5 & 8.3 & 23.6 & 8.6 & 14.5 & 35 & 3.5 & 10.5 \\
BI & 245.9 & 392.3 & 245.9 & 5051 & 21656 & 28.9 & 59.8 & 23.3 & 70.6 & 28.7 \\
SY & 75.2 & 149.2 & 75.2 & 962 & 3429 & 41.2 & 77.8 & 28.1 & 33.9 & 45.1 \\
\hline
\end{tabular}

Traits, $\mathrm{DFF}=$ days to $50 \%$ flowering, $\mathrm{DM}=$ days to $90 \%$ maturity, $\mathrm{NP}=$ number of pods per plant, $\mathrm{NS}=$ number of seeds per pod, NSPP $=$ number of seeds per plant, $\mathrm{PH}=$ plant height in $\mathrm{cm}, \mathrm{SW}=100$-seed weight in gram, $\mathrm{BI}=$ above ground biomass, $\mathrm{SY}=$ seed yield .

$\mathrm{GV}=$ genotypic variance, $\mathrm{PV}=$ phenotypic variance, $\mathrm{GCV}=$ genetic coefficient of variation, $\mathrm{PCV}=$ phenotypic coefficient of variation, $h^{2}=$ broad sense of heritability, GA = genetic advance, GAM = genetic advance as the percentage of the mean.

TABLE 10: Genetic parameter estimates for agromorphological characters of lentil genotypes at Chefe Donsa 2011/12 cropping season.

\begin{tabular}{lcccccccccc}
\hline Traits & Test genotype mean & Check mean & Grand mean & GV & PV & PCV & GCV & $h^{2}$ & GA & GAM \\
\hline DFF & 55.9 & 57.3 & 55.9 & 14.9 & 29.3 & 6.9 & 9.7 & 50.6 & 5.6 & 10.1 \\
DM & 114.1 & 113.2 & 114.1 & 39.4 & 130.5 & 5.5 & 10.0 & 30.2 & 7.1 & 6.2 \\
NP & 26.9 & 35.3 & 26.9 & 4.6 & 185.3 & 7.9 & 50.0 & 2.5 & 0.7 & 2.6 \\
NS & 1.5 & 1.4 & 1.5 & 0.1 & 0.1 & 1.4 & 15.8 & 0.7 & 0.005 & 0.3 \\
NSPP & 41.3 & 50.2 & 41.3 & 2.2 & 502.4 & 3.6 & 53.9 & 0.4 & 0.2 & 0.4 \\
SWPP & 1.1 & 1.4 & 1.1 & 0.03 & 0.3 & 17.8 & 54 & 10.9 & 0.1 & 11.2 \\
SW & 2.8 & 2.7 & 2.8 & 0.5 & 0.6 & 23.7 & 26.2 & 81.8 & 1.3 & 46.6 \\
PH & 27.5 & 28.5 & 27.5 & 6.4 & 14.3 & 9.2 & 13.7 & 45.2 & 3.5 & 12.8 \\
BI & 262.6 & 305.6 & 262.6 & 2789.0 & 9888.0 & 20 & 37.6 & 28.2 & 57.8 & 22.0 \\
SY & 82.5 & 107.6 & 82.5 & 460.2 & 1427 & 25.7 & 45.3 & 32.3 & 25.1 & 30.5 \\
RSAF & 3.6 & 3.1 & 3.6 & 3.1 & 4.9 & 49.1 & 61.7 & 63.2 & 2.9 & 80.1 \\
\hline
\end{tabular}

The lowest PCV (10\%) was recorded for days to $50 \%$ flowering and the highest $(60.7 \%)$ for pod weight/plant at Sirinka 2010/2011. At Sirinka 2010/2011, GCV values ranged from $7.6 \%$ for days to $50 \%$ flowering to $58.4 \%$ for pod weight/plant (Table 8). The maximum PCV and GCV recorded for number of pods/plant were 89.8 and 75 , respectively, at Sirinka 2012, while the lowest PCV and GCV recorded for plant height were 14.5 and 8.6, respectively (Table 9). Days to $90 \%$ maturity and 100-seed weight showed moderate GCV. At Chefe Donsa and Sinana, values recorded for both PCV and GCV were similar with those of Sirinka (Tables 10 and 11). Traits such as number of pods/plant, seed weight/plant, 100seed weight, above ground biomass, seed yield, and rust disease score showed relatively high PCV and GCV values across the four environments (Tables 8-11).

3.3. Heritability and Genetic Advance. The broad sense of heritability $\left(H^{2}\right)$ estimates of the traits ranged from $0.4 \%$ (number of seeds/plant) to $92.6 \%$ (pod weight/plant). According to [34], heritability estimate in cultivated plants can be placed in the following categories: heritability estimate ranging from 5 to $10 \%$ low, values ranging from 10 to $30 \%$ medium, and values $30 \%$ and above as high heritability. Based on the above classification, most of the characters have shown high heritability over locations except at Chefe Donsa. At
Chefe Donsa, low heritability estimates were recorded for number of seeds/plant $(0.4 \%)$, number of seeds/pods $(0.7 \%)$, and number of pods/plant (2.5\%) (Table 10). At Sinana, heritability estimates ranged from $18 \%$ to $88 \%$ for biomass and 100-seed weight, respectively. Days to $90 \%$ maturity, number of seeds/plant, plant height, and above ground biomass had a moderate heritability (17.7-26.1\%) (Table 11), whereas seed yield, 100-seed weight, rust disease score, number of pods/plant, and number of seeds/plant scored higher heritability.

Consistently higher value of heritability was revealed for days to $50 \%$ flowering, 100 -seed weight, days to $90 \%$ maturity, and plant height over locations. However, all these four characters associated with low genetic advance value (GA) because of low GCV, whereas 100-seed weight, rust severity score, and seed yield showed high heritability values coupled with high genetic advance values across locations because of high of GCV. Numbers of seeds/plant, seed weight/plant, and number of seeds/pod have intermediate GCV and heritability with a mild response to selection.

\section{Discussion}

Morphological diversity has been used to characterize germplasm from a range of plant species and allows the assessment 
TABLE 11: Genetic parameter estimates for agromorphological characters of lentil genotypes at Sinana 2011/12 cropping season.

\begin{tabular}{lcccccccccc}
\hline Traits & Test genotype mean & Check mean & Grand mean & GV & PV & PCV & GCV & $h^{2}$ & GA & GAM \\
\hline DFF & 66.04 & 66.8 & 66.1 & 20.7 & 66.6 & 6.9 & 12.4 & 31.1 & 7.9 & 12.1 \\
DM & 105.1 & 104.5 & 105.1 & 86.6 & 331.2 & 2.4 & 15.1 & 26.1 & 9.8 & 9.3 \\
NP & 19.2 & 20.8 & 19.3 & 33.7 & 63.6 & 30.2 & 41.4 & 52.9 & 8.6 & 44.4 \\
NSPP & 33.9 & 36.1 & 34 & 33.1 & 149.6 & 16.9 & 36 & 22.1 & 13.1 & 38.5 \\
SW & 2.38 & 2.7 & 2.4 & 0.6 & 0.7 & 32.7 & 35 & 87.1 & 1.51 & 63.2 \\
PH & 40.3 & 42.6 & 40.4 & 7.2 & 30.1 & 6.6 & 13.6 & 23.7 & 2.7 & 6.7 \\
BI & 505.1 & 619.1 & 509.1 & 6290 & 35625 & 15.6 & 37.1 & 17.7 & 69.9 & 13.8 \\
SY & 40.2 & 89.6 & 41.9 & 809.8 & 1633 & 67.9 & 96.4 & 49.6 & 45.8 & 109.2 \\
RSBF & 2 & 1.5 & 1.9 & 1.2 & 2 & 55.6 & 71.9 & 59.7 & 1.8 & 88.9 \\
RSAF & 5.8 & 4.6 & 5.7 & 1.2 & 5.1 & 19.5 & 39.4 & 24.5 & 1.2 & 21.1 \\
\hline
\end{tabular}

of genetic diversity. The purpose of this study was to compare the genetic diversity within and among Ethiopian and exotic lentil genotypes of the Ethiopian possessions. In this paper, the characterizations of morphological variation of lentil germplasm using biometrical model was described.

As per ANOVA, highly significant phenotypic $(P \leq 0.01)$ differences were observed for all traits measured indicating the existence of variation. The presence of highly significant variation among the genotypes for the morphological traits was indicative of the presence of high degree of genetic variation for future breeding programs through selection. Similarly, from follow-up study with the simple sequence repeat (SSR), genetic diversity analysis was a supportive evidence of the presence of a considerable variability among both local and exotic lentil genotypes of the Ethiopia germplasm (unpublished data). In agreement with this report, [21, 3439] reported significant genetic variations among lentil landraces. On the other hand, some studies showed that no significant variation was recorded for some traits, like seed weight/plant and days to flowering $[21,38,40]$.

The results recorded for coefficient of variation were comparable with [38] for days to 50\% flowering (8.8), plant height (9.1), number of seeds/plant (43.2), and above ground biomass (31.5). However, [38] reported higher values vis$a$-vis with this study for days to $90 \%$ maturity (19.2), pod weight/plant (47), and seed weight/plant (47.8). In agreement with this finding, [41] also noted comparable range for plant height on 3974 accessions of lentil. However, they recorded a wider range of values for 100-seed weight with an overall mean than with our records on lentil accessions. In another study, [37] reported a narrow range for yield component traits among 46 genotypes from South East Anatolia region of Turkey as opposed to our findings.

Significant variations were noted over locations among the test genotypes and within the checks with a few exceptions. In line with this study, [24] recorded the wide range of genetic variability among yield related characters in exotic lentil lines in Ethiopia. Comparable to our study, [15, 18] noted the presence of variation in characters, such as grain and straw yield, 100-seed weight, days to 50\% flowering, days to $90 \%$ maturity, number of seeds/pods, plant height, pod number/peduncle, and resistance to various biotic and a biotic stresses in the lentil. Besides, the variation among environments was significant for all morphological traits in view of diverse agro-climatic features of the test sites. Similarly, [42] also observed the greater portion of total variance was due to environment. Reference $[5,7,23]$ also reported consistent regional differences among lentil landraces of Ethiopia for time to flowering and maturity, 100seed weight, seed/pod, and plant height.

ANOVA over locations showed consistent significant variations were recorded within the checks for 100-seed weight, above ground biomass, seed yield, and rust disease score. These implied that yield increment was achieved for the last three decades, largely for 100-seed weight, above ground biomass, and seed yield of lentil genotypes. A consistent significant variation was also recorded within test genotypes over three locations for days to $50 \%$ flowering and 100 -seed weight. Besides, reliable variation was noted over all locations between checks and test genotypes for above ground biomass and seed yield. Similarly, according to this (unpublished data) follow-up study, using the multivariate analysis reported that seed yield, above ground biomass, seed weight/plant, 100seed weight, rust severity score, and plant height were the major agromorphological traits contributing to variations among the genotypes.

Estimate of PCV and GVC for days to 50\% flowering, days to $90 \%$ maturity, and 100 -seed weight showed narrow differences, indicating a relatively low influence of the environment on these characters. Similar observation of considerable closeness between GCV and PCV for these characters made by [43] indicated low influence of environmental factors in lentil. In general, PCV values for most of the traits at Sirinka and Sinana were higher than that record noted at Chefe Donsa. In addition, the PCV was generally higher than the GCV for all characters. Consistently higher PCV values were observed across four environments for rust disease scores, seed yield, pod weight/plant, seed weight/plant, number of pods/plant, 100-seed weight, above ground plant biomass, and number of seeds/plant. Other studies showed similar high PCV and GCV for seed yield, above ground biomass, and 100-seed weight [44, 45]. In contrast, days to $50 \%$ flowering, days to $90 \%$ maturity, and plant height showed comparatively low PCV values (less than 20\%) for all locations. It was observed that GCV for number of pods/plant, seed yield, rust disease score, 100 -seed 
TABLE 12: Means for yield and yield components of the genotypes at Sirinka 2010/11.

\begin{tabular}{|c|c|c|c|c|c|c|c|c|c|c|c|c|}
\hline Genotype name & DF & $\mathrm{DM}$ & $\mathrm{NP}$ & NSS & PWPP & SWPP & NSPP & $\mathrm{PHH}$ & SW & BI & SY & PSS \\
\hline 36001 & 57 & 89 & 39.7 & 0.9 & 1.8 & 1.2 & 39 & 44.7 & 2.6 & 345.2 & 78 & 5 \\
\hline 36003 & 56 & 91 & 47.8 & 0.7 & 1.9 & 0.9 & 45 & 38.8 & 2.1 & 315.7 & 59.9 & 6 \\
\hline 36007 & 58 & 90 & 38.8 & 1.8 & 2 & 1.5 & 86 & 38.4 & 2.1 & 359.3 & 79.6 & 6 \\
\hline 36009 & 58 & 90 & 35.6 & 1.3 & 1.4 & 0.9 & 47 & 39.9 & 1.9 & 294.8 & 60.9 & 5 \\
\hline 36013 & 58 & 90 & 39.8 & 1.2 & 3.9 & 2.3 & 52 & 39.4 & 2.1 & 440.8 & 74 & 5 \\
\hline 36015 & 59 & 98 & 29.7 & 1.9 & 1.9 & 1.2 & 52 & 41.9 & 2.5 & 545.8 & 128.6 & 5 \\
\hline 36019 & 55 & 94 & 41.1 & 1.2 & 1.9 & 1.5 & 69 & 37 & 2.2 & 311.9 & 71.6 & 5 \\
\hline 36023 & 54 & 84 & 34.5 & 0.6 & 1.6 & 0.6 & 41 & 36.8 & 2.1 & 237.8 & 30.6 & 5 \\
\hline 36025 & 46 & 77 & 34.2 & 1.1 & 2 & 1.1 & 39 & 33.6 & 2.1 & 254.7 & 62.2 & 6 \\
\hline Alemaya & 57 & 107 & 55.2 & 1.3 & 1.5 & 2.4 & 70 & 31.6 & 3.1 & 449.6 & 160.9 & 6 \\
\hline ADAA & 61 & 128 & 29.1 & 1.7 & 1.9 & 1.3 & 43 & 40.4 & 2.8 & 249.7 & 45.9 & 4 \\
\hline EL-142 & 56 & 93 & 36.1 & 1.1 & 1.1 & 1 & 45 & 35.5 & 2 & 321.8 & 51.1 & 5 \\
\hline X2003S 222/213/ & 66 & 103 & 32.7 & 1.1 & 1.7 & 1.1 & 36 & 36 & 2 & 390.8 & 95.2 & 4 \\
\hline X2003S 238 & 55 & 92 & 32.5 & 1.1 & 2.3 & 1.4 & 40 & 32.2 & 3.8 & 377.4 & 124.8 & 6 \\
\hline 36028 & 59 & 98 & 38.2 & 0.7 & 1.4 & 1.3 & 52 & 41.1 & 2.2 & 453 & 145.6 & 6 \\
\hline 36029 & 57 & 89 & 39.9 & 1.3 & 2.1 & 1.1 & 49 & 31.8 & 2.3 & 331.6 & 76.7 & 5 \\
\hline 36033 & 55 & 86 & 37.4 & 1 & 1.3 & 1 & 37 & 33.8 & 2.4 & 257.9 & 78.4 & 7 \\
\hline 36039 & 55 & 88 & 43.5 & 1.2 & 2.1 & 1.2 & 68 & 33.6 & 2.3 & 181.4 & 60.9 & 5 \\
\hline 36041 & 56 & 89 & 55.4 & 1.1 & 1.8 & 1.4 & 60 & 34.7 & 2.1 & 246.5 & 75.9 & 5 \\
\hline 36048 & 57 & 88 & 52.7 & 0.9 & 1 & 1.3 & 49 & 35.1 & 1.8 & 280.4 & 89.2 & 5 \\
\hline 36058 & 51 & 84 & 41.1 & 0.6 & 0.9 & 0.8 & 40 & 32.1 & 2.9 & 170.5 & 55.2 & 6 \\
\hline 36061 & 54 & 82 & 36.3 & 0.6 & 0.8 & 0.6 & 22 & 30.5 & 2 & 163.3 & 30.8 & 6 \\
\hline TESHALE & 56 & 98 & 26.9 & 1.2 & 2 & 1.3 & 34 & 33.7 & 3.6 & 372.9 & 119.7 & 5 \\
\hline X2006S 128/5480/ & 77 & 125 & 50 & 1.2 & 4.6 & 2 & 59 & 42.9 & 2.8 & 767.8 & 153.3 & 3 \\
\hline L-9-12 & 59 & 114 & 35.3 & 1 & 1.5 & 1.2 & 38 & 36.7 & 3.6 & 316 & 74 & 4 \\
\hline 36071 & 57 & 91 & 33.1 & 0.9 & 1 & 0.9 & 39 & 41.5 & 2.4 & 406.5 & 104.6 & 6 \\
\hline 36085 & 57 & 91 & 58 & 1.2 & 2 & 1.9 & 77 & 39.8 & 3 & 392.7 & 117.2 & 6 \\
\hline 36088 & 57 & 95 & 34.4 & 1.1 & 1.2 & 0.9 & 40 & 37.5 & 3 & 399.6 & 115.3 & 5 \\
\hline 36089 & 60 & 97 & 32.7 & 1.1 & 0.5 & 1.1 & 41 & 33.3 & 2.3 & 237.2 & 105.8 & 5 \\
\hline 36097 & 58 & 98 & 56.4 & 1 & 1.7 & 1.5 & 75 & 34.9 & 2.4 & 288.9 & 86.5 & 4 \\
\hline 36098 & 56 & 106 & 18.3 & 0.5 & 0.5 & 0.2 & 6 & 29.9 & 2.1 & 71.1 & 0.1 & 4 \\
\hline 36103 & 53 & 86 & 27.5 & 1.4 & 1.3 & 1 & 36 & 35.6 & 2.5 & 274.4 & 90.9 & 5 \\
\hline 36104 & 53 & 88 & 37.2 & 1.1 & 1.7 & 1.3 & 45 & 34.9 & 2.7 & 274.5 & 77.3 & 6 \\
\hline 36105 & 56 & 87 & 29.7 & 1.1 & 0.3 & 0.8 & 33 & 29.8 & 3.1 & 145 & 41.6 & 5 \\
\hline 211062 & 60 & 91 & 38.9 & 1.6 & 1.9 & 1.6 & 63 & 37 & 2 & 449.4 & 93.9 & 5 \\
\hline X2003S 195 & 72 & 130 & 35.2 & 1.2 & 1.5 & 1.1 & 43 & 34.6 & 2.5 & 287.1 & 84.3 & 5 \\
\hline X2002S 219/6821/ & 57 & 96 & 35.2 & 1.2 & 1.5 & 1.1 & 43 & 34.6 & 2.5 & 287.1 & 84.3 & 5 \\
\hline X2006S 129/F2 & 51 & 94 & 28.6 & 1.2 & 1.5 & 1.1 & 43 & 34.6 & 2.5 & 287.1 & 84.3 & 5 \\
\hline 36110 & 57 & 91 & 40.9 & 1.7 & 2.1 & 1.7 & 68 & 39.8 & 2.2 & 374.5 & 136.5 & 5 \\
\hline 36120 & 42 & 87 & 23.3 & 0.5 & 1 & 0.4 & 12 & 25.7 & 2.2 & 174 & 30.3 & 7 \\
\hline 36131 & 59 & 92 & 36.3 & 1.6 & 1.2 & 1.4 & 59 & 37.1 & 2.1 & 369 & 127.4 & 5 \\
\hline 36042 & 54 & 84 & 45.5 & 0.8 & 2.2 & 0.9 & 37 & 35.4 & 1.9 & 223.4 & 48 & 6 \\
\hline 36137 & 59 & 99 & 33.2 & 1.4 & 1.5 & 0.9 & 44 & 34 & 2.1 & 251 & 78.6 & 4 \\
\hline 36139 & 53 & 97 & 40.7 & 0.9 & 1.8 & 0.7 & 34 & 35.8 & 2 & 243.6 & 55.8 & 6 \\
\hline 36147 & 60 & 99 & 48 & 1.1 & 1.8 & 1.2 & 50 & 38.8 & 2.4 & 331.6 & 97.7 & 6 \\
\hline 36150 & 56 & 89 & 34.4 & 1.3 & 1.9 & 0.8 & 46 & 35.9 & 2.4 & 261.6 & 76.3 & 5 \\
\hline 36162 & 57 & 100 & 34.7 & 1.3 & 2 & 1 & 43 & 36.6 & 2.3 & 237.1 & 67 & 5 \\
\hline 36165 & 57 & 95 & 30.3 & 1.4 & 0.9 & 1 & 44 & 39 & 2.4 & 313.9 & 83.4 & 6 \\
\hline X2005S 215/6002/ & 57 & 96 & 34.1 & 0.8 & 1.6 & 1 & 25 & 40.8 & 3.9 & 329.8 & 101.7 & 5 \\
\hline 36168 & 59 & 104 & 26.6 & 1 & 1.1 & 0.9 & 27 & 34.1 & 2.5 & 267.5 & 89.7 & 5 \\
\hline 203141 & 59 & 90 & 41.1 & 1 & 1.5 & 1.3 & 42 & 35.4 & 2.3 & 320.5 & 118.4 & 5 \\
\hline
\end{tabular}


TABle 12: Continued.

\begin{tabular}{|c|c|c|c|c|c|c|c|c|c|c|c|c|}
\hline Genotype name & $\mathrm{DF}$ & $\mathrm{DM}$ & NP & NSS & PWPP & SWPP & NSPP & $\mathrm{PHH}$ & SW & $\mathrm{BI}$ & SY & PSS \\
\hline 207258 & 58 & 90 & 50 & 1 & 1.3 & 1.2 & 47 & 39.1 & 2.6 & 324.7 & 104.2 & 6 \\
\hline 207274 & 59 & 91 & 39.9 & 1.1 & 1.5 & 1.3 & 48 & 38.1 & 2.3 & 272.5 & 99.2 & 5 \\
\hline 207260 & 58 & 94 & 40.9 & 1.2 & 0.9 & 1.1 & 52 & 38.3 & 2.3 & 340.3 & 92.7 & 5 \\
\hline 207287 & 52 & 91 & 46.4 & 1.1 & 2.3 & 1.4 & 51 & 35.1 & 2.2 & 311.9 & 107.1 & 6 \\
\hline 207309 & 57 & 89 & 36.9 & 1 & 1.3 & 1 & 35 & 31.8 & 2.3 & 248.1 & 57 & 5 \\
\hline 211078 & 54 & 88 & 47.9 & 1.4 & 2.1 & 1.5 & 61 & 31 & 2.1 & 218.6 & 70.3 & 6 \\
\hline 211131 & 53 & 87 & 40.7 & 1.7 & 1.4 & 1.8 & 65 & 32.3 & 2 & 260.4 & 102 & 6 \\
\hline 212745 & 57 & 91 & 36.3 & 1.5 & 1.9 & 1.2 & 57 & 33.3 & 2.2 & 322.7 & 106.9 & 7 \\
\hline X2006S 133/6211/ & 53 & 98 & 18 & 1.3 & 1.2 & 0.7 & 20 & 30.5 & 3.7 & 135.5 & 36.4 & 5 \\
\hline 238979 & 59 & 91 & 60.1 & 1.3 & 2.3 & 1.9 & 81 & 33 & 2.1 & 259.2 & 88.6 & 5 \\
\hline 215248 & 56 & 87 & 45.5 & 1.2 & 1.5 & 1.2 & 51 & 31.4 & 2.2 & 237.5 & 71.4 & 5 \\
\hline 215249 & 58 & 90 & 39.7 & 1.4 & 1.1 & 1.6 & 53 & 35.7 & 2.4 & 265.7 & 87 & 5 \\
\hline 215806 & 58 & 91 & 26 & 1.8 & 0.8 & 0.8 & 35 & 32.9 & 2.5 & 189.6 & 56.8 & 5 \\
\hline 216877 & 58 & 92 & 29.3 & 1.3 & 0.6 & 0.8 & 35 & 33.4 & 2.1 & 226.8 & 82.4 & 4 \\
\hline 220120 & 56 & 91 & 23.6 & 1.3 & 0.7 & 0.6 & 27 & 37.7 & 2 & 149.7 & 34.9 & 6 \\
\hline 223221 & 58 & 89 & 23.3 & 1.5 & 0.8 & 0.7 & 35 & 34.7 & 2 & 216.9 & 72.8 & 5 \\
\hline 228242 & 59 & 90 & 34.9 & 1.8 & 1.5 & 1.4 & 65 & 37.3 & 2.2 & 259.5 & 83.5 & 5 \\
\hline 228243 & 59 & 87 & 24.6 & 1.9 & 0.6 & 0.5 & 43 & 33.1 & 2 & 132.5 & 35.2 & 5 \\
\hline 228809 & 53 & 87 & 32.4 & 0.6 & 1 & 0.7 & 21 & 35.9 & 2 & 231.1 & 63.9 & 5 \\
\hline 219957 & 53 & 97 & 31.3 & 1.2 & 0.5 & 1 & 41 & 37.3 & 2.5 & 351.3 & 107.4 & 6 \\
\hline 211110 & 59 & 91 & 38.9 & 1.8 & 1.6 & 1.2 & 62 & 38.4 & 1.8 & 390 & 96.3 & 5 \\
\hline 229179 & 59 & 97 & 29.7 & 1.8 & 1.1 & 0.9 & 53 & 40.3 & 2.2 & 296.5 & 72.3 & 5 \\
\hline 229182 & 59 & 95 & 40.5 & 1 & 1.1 & 1.1 & 43 & 41 & 2.2 & 342.6 & 83.3 & 5 \\
\hline 229183 & 59 & 92 & 29.8 & 1.3 & 1 & 0.8 & 40 & 36 & 2.2 & 265.6 & 64.8 & 5 \\
\hline 230521 & 59 & 93 & 28.7 & 1.3 & 1.2 & 0.7 & 40 & 38.2 & 1.9 & 366.7 & 99.2 & 5 \\
\hline 230832 & 59 & 93 & 43.3 & 1.3 & 0.9 & 1 & 54 & 38.2 & 1.7 & 270.8 & 81.8 & 5 \\
\hline 230833 & 59 & 93 & 52.6 & 1 & 1.1 & 1.4 & 60 & 36.9 & 2 & 327.3 & 91.5 & 5 \\
\hline 230834 & 58 & 93 & 27 & 1.5 & 1 & 0.7 & 37 & 34.7 & 1.8 & 346.2 & 94.1 & 4 \\
\hline 230837 & 58 & 90 & 44.9 & 0.8 & 1.6 & 1 & 35 & 35.9 & 1.9 & 402.6 & 118.2 & 4 \\
\hline 231247 & 59 & 93 & 36.4 & 1.2 & 1.1 & 1.1 & 44 & 35.6 & 2.3 & 297.5 & 103.4 & 6 \\
\hline 231248 & 58 & 88 & 42.6 & 0.7 & 1 & 1 & 29 & 32.2 & 2.4 & 301.5 & 89.7 & 5 \\
\hline X2006S 130/7547/ & 54 & 86 & 20.9 & 0.7 & 0.7 & 0.4 & 13 & 27.1 & 2.3 & 91.8 & 98.3 & 6 \\
\hline FLIP-2004-7L & 51 & 99 & 17.6 & 1.6 & 1.4 & 1.3 & 28 & 32 & 4.9 & 270.8 & 92.8 & 4 \\
\hline 233349 & 57 & 90 & 19.8 & 1.2 & 1.1 & 0.6 & 26 & 30.2 & 2.5 & 159.2 & 43 & 5 \\
\hline 233973 & 57 & 89 & 30.6 & 1.5 & 1.2 & 1 & 40 & 31.8 & 2.4 & 252.4 & 143 & 4 \\
\hline X2003S 223 & 66 & 124 & 1.6 & 0.8 & 8.1 & 0.4 & 6 & 25 & 2.9 & 35 & 0 & 5 \\
\hline X2003S 195/7115/ & 57 & 96 & 35.2 & 1.2 & 1.5 & 1.1 & 43 & 34.6 & 2.5 & 287.1 & 84.3 & 5 \\
\hline 235013 & 57 & 91 & 23.6 & 1.3 & 2.3 & 1.1 & 31 & 30.7 & 2.5 & 248.3 & 92.7 & 5 \\
\hline 235015 & 58 & 91 & 45.4 & 1.1 & 2.2 & 1.2 & 50 & 35.5 & 2.4 & 199.6 & 66.8 & 5 \\
\hline 235016 & 58 & 89 & 29.2 & 1.1 & 1.7 & 0.9 & 32 & 33.3 & 2.7 & 284.1 & 91.6 & 5 \\
\hline 235017 & 58 & 91 & 38.4 & 1.1 & 1.3 & 0.8 & 42 & 33 & 2.4 & 196.6 & 66.9 & 5 \\
\hline 235383 & 57 & 89 & 36.2 & 1.2 & 1.9 & 1.2 & 47 & 40.8 & 2.6 & 310 & 97.9 & 6 \\
\hline 235698 & 53 & 88 & 52.1 & 0.8 & 1.4 & 1 & 40 & 33.6 & 2.2 & 196.8 & 68.3 & 5 \\
\hline 236438 & 58 & 90 & 33.2 & 0.9 & 1.2 & 0.8 & 30 & 34.5 & 2 & 358.1 & 113.7 & 5 \\
\hline 236484 & 57 & 88 & 52.2 & 1 & 1.7 & 1.4 & 51 & 33.6 & 2.1 & 273.1 & 87 & 6 \\
\hline X2006S 130/7978/ & 56 & 92 & 40.8 & 1 & 1.9 & 1.6 & 39 & 35.9 & 4.1 & 334.6 & 101.3 & 5 \\
\hline X2002S 221/7979/ & 46 & 89 & 20.5 & 0.8 & 0.9 & 0.6 & 18 & 33.3 & 2.3 & 176.6 & 40.7 & 5 \\
\hline X2002S 221/7980/ & 58 & 99 & 28.9 & 0.9 & 1.7 & 1.5 & 30 & 36.1 & 4.2 & 310.7 & 109.1 & 5 \\
\hline 236486 & 57 & 88 & 30.5 & 0.9 & 0.8 & 0.9 & 34 & 35 & 2.2 & 183.4 & 61.9 & 5 \\
\hline 236487 & 53 & 88 & 36 & 1.4 & 0.8 & 1 & 39 & 33.4 & 2.3 & 207.3 & 73 & 5 \\
\hline 236892 & 58 & 91 & 36.9 & 1.1 & 1 & 0.9 & 41 & 37.7 & 2.2 & 240.3 & 59.8 & 5 \\
\hline
\end{tabular}


TABLE 12: Continued.

\begin{tabular}{|c|c|c|c|c|c|c|c|c|c|c|c|c|}
\hline Genotype name & $\mathrm{DF}$ & $\mathrm{DM}$ & $\mathrm{NP}$ & NSS & PWPP & SWPP & NSPP & $\mathrm{PHH}$ & SW & $\mathrm{BI}$ & SY & PSS \\
\hline 237027 & 50 & 83 & 25.3 & 0.8 & 1.1 & 0.7 & 21 & 33.3 & 3.9 & 146.9 & 47.3 & 5 \\
\hline 237502 & 60 & 90 & 36.8 & 1.2 & 1 & 0.9 & 44 & 33.8 & 2.1 & 195.5 & 54.1 & 5 \\
\hline 237503 & 59 & 92 & 41.8 & 1.5 & 1.2 & 1.4 & 67 & 39.3 & 2.6 & 279.9 & 93.9 & 5 \\
\hline 237504 & 59 & 92 & 45.4 & 0.9 & 1.8 & 1.1 & 39 & 36.4 & 2.3 & 227.3 & 76.2 & 5 \\
\hline X2003S 224 & 57 & 96 & 35.2 & 1.2 & 1.5 & 1.1 & 43 & 34.6 & 2.5 & 287.1 & 84.3 & 5 \\
\hline 238971 & 58 & 90 & 31 & 1.5 & 1.1 & 0.9 & 42 & 32.8 & 2.5 & 262.8 & 80.7 & 5 \\
\hline 238978 & 60 & 97 & 31.2 & 0.9 & 0.7 & 0.8 & 33 & 35.8 & 2.4 & 247.4 & 70.7 & 4 \\
\hline X2003S 233/8009/ & 51 & 85 & 19.8 & 2 & 1.4 & 0.4 & 29 & 27.4 & 1.4 & 75.8 & 30.3 & 2 \\
\hline X2006S 134/8174/ & 67 & 119 & 45 & 1.2 & 3.2 & 1.8 & 54 & 40.5 & 2.9 & 413.9 & 75.6 & 5 \\
\hline X2006S 127 & 72 & 124 & 29.1 & 0.9 & 1 & 0.7 & 28 & 31.7 & 2.2 & 188.8 & 28.7 & 3 \\
\hline 241782 & 59 & 109 & 26.6 & 1.4 & 0.8 & 0.6 & 28 & 36.2 & 2.4 & 268.5 & 66.5 & 4 \\
\hline 241784 & 56 & 90 & 36 & 1.2 & 1.6 & 1.2 & 41 & 36.5 & 2.6 & 282 & 98 & 6 \\
\hline 241785 & 57 & 88 & 35.1 & 1 & 1.1 & 1.1 & 36 & 34.8 & 2.6 & 276 & 95.6 & 5 \\
\hline 241786 & 55 & 87 & 51.3 & 1.2 & 1.4 & 1.7 & 69 & 35.4 & 2.4 & 391.6 & 145.4 & 5 \\
\hline 242604 & 58 & 92 & 52.6 & 1.2 & 2.2 & 1.8 & 65 & 36.3 & 2.5 & 392.4 & 134.8 & 6 \\
\hline 243433 & 59 & 94 & 32.4 & 0.9 & 1.4 & 1 & 28 & 32.8 & 2.3 & 241.3 & 73.2 & 5 \\
\hline 243436 & 59 & 91 & 24.1 & 1.1 & 1.1 & 0.6 & 28 & 27.2 & 2.3 & 117.3 & 35 & 5 \\
\hline 243440 & 57 & 94 & 30.7 & 0.7 & 1.1 & 1 & 20 & 35.8 & 2.3 & 244.1 & 88.5 & 5 \\
\hline 243443 & 53 & 94 & 27.1 & 1.1 & 1.5 & 1 & 26 & 34.9 & 2.5 & 273.4 & 82.2 & 5 \\
\hline 243447 & 53 & 94 & 26.9 & 1.1 & 2.2 & 1.1 & 26 & 34.7 & 2.7 & 257.9 & 95.7 & 6 \\
\hline X2006S 122/9932/ & 54 & 86 & 18.1 & 1 & 0.9 & 0.5 & 20 & 30.5 & 2.1 & 163.4 & 31.4 & 5 \\
\hline X2006S 127/9945/ & 51 & 90 & 27.6 & 0.8 & 1 & 0.5 & 21 & 28.2 & 2.4 & 206.7 & 42.1 & 4 \\
\hline 244606 & 53 & 85 & 26.6 & 1.2 & 1 & 0.7 & 34 & 31.7 & 2.2 & 258.2 & 83.2 & 5 \\
\hline 244610 & 53 & 85 & 33.8 & 1.3 & 1.5 & 0.9 & 50 & 34.8 & 2.2 & 222.1 & 86.8 & 5 \\
\hline 244615 & 58 & 85 & 34.7 & 1.2 & 1.7 & 0.9 & 42 & 33.6 & 2.2 & 261.3 & 75.8 & 5 \\
\hline 244619 & 58 & 87 & 33.8 & 1.2 & 1.2 & 0.8 & 32 & 36.7 & 2 & 227.2 & 65.1 & 5 \\
\hline 244623 & 53 & 85 & 26.4 & 1 & 1.3 & 0.7 & 29 & 37.8 & 2.3 & 263.2 & 65.3 & 5 \\
\hline X2006S 122/9951/ & 53 & 88 & 36.3 & 1.3 & 2.1 & 1.1 & 41 & 33 & 1.8 & 240.1 & 64.6 & 6 \\
\hline X2002S 219/shehor-74/7554 & 46 & 82 & 10.2 & 0.8 & 0.7 & 0.1 & 8 & 28.8 & 2.5 & 59.7 & 9.1 & 6 \\
\hline ILL-590 & 56 & 87 & 40.7 & 1.3 & 1.2 & 1.1 & 42 & 35.6 & 3.2 & 468.3 & 347.3 & 6 \\
\hline X2003S 236 & 57 & 96 & 35.2 & 1.2 & 1.5 & 1.1 & 43 & 34.6 & 2.5 & 287.1 & 84.3 & 6 \\
\hline EXOTIC \#DZ/2008 AK & 61 & 115 & 12.2 & 1.2 & 1.5 & 1 & 16 & 31.8 & 3.3 & 564.3 & 96.4 & 5 \\
\hline R-186XFLIP-86-38L-24 & 60 & 109 & 73.3 & 1.4 & 1.5 & 3.4 & 103 & 37.1 & 2.8 & 642.9 & 200.9 & 4 \\
\hline FLIP-2006-60L & 54 & 126 & 23 & 1.3 & 1.5 & 1 & 31 & 24.6 & 3.4 & 200 & 54.3 & 5 \\
\hline FLIP-97-68L & 56 & 104 & 46.1 & 1.3 & 1.5 & 1.7 & 59 & 31.1 & 3.1 & 541.5 & 165.1 & 5 \\
\hline ILL-358 X ILL-2573-2-2000 & 64 & 112 & 32 & 1.4 & 1.5 & 1.2 & 46 & 30.4 & 2.9 & 288.1 & 99.5 & 5 \\
\hline FLIP-04-26L & 78 & 138 & 30 & 1.1 & 1.5 & 1.2 & 26 & 38.1 & 4.2 & 578.8 & 61.2 & 5 \\
\hline ILL-28501 & 58 & 114 & 36.2 & 1.6 & 1.5 & 1.6 & 59 & 37.7 & 3.1 & 389.1 & 98 & 5 \\
\hline 87S-93549XEL-1O3-4 & 47 & 95 & 33.2 & 1.1 & 1.5 & 1 & 37 & 27.9 & 2.6 & 215.8 & 81.2 & 5 \\
\hline 87s-93549XEL-103-5 & 57 & 109 & 31.6 & 1.4 & 1.5 & 0.9 & 46 & 36.4 & 2.6 & 374.7 & 109.7 & 5 \\
\hline FLIP-2006-20L & 74 & 124 & 20.4 & 1 & 1.5 & 0.8 & 21 & 31.8 & 3.2 & 295.8 & 30.9 & 5 \\
\hline Derash & 57 & 103 & 55.5 & 1.3 & 1.5 & 2.5 & 71 & 35.6 & 3 & 446 & 162.2 & 5 \\
\hline ALEMETENA & 50 & 94 & 25.3 & 1.2 & 1.5 & 1.1 & 33 & 21.9 & 3.6 & 172.2 & 85.6 & 5 \\
\hline Chekol x R-186-8-1 & 54 & 109 & 30.7 & 1.2 & 1.5 & 1.3 & 38 & 31.1 & 3.3 & 303 & 119.2 & 5 \\
\hline R-186X FLIP-86-38L & 58 & 103 & 27.2 & 1.8 & 1.5 & 1.4 & 50 & 31.9 & 2.5 & 262.9 & 80.5 & 5 \\
\hline FLIP-87-68L & 60 & 122 & 41 & 1.3 & 1.5 & 1.7 & 60 & 29.3 & 3.1 & 266 & 93 & 5 \\
\hline Chekol & 57 & 98 & 38 & 1.4 & 1.5 & 1.1 & 54 & 29.4 & 2.3 & 258.1 & 104.8 & 5 \\
\hline ILL-10045 & 60 & 115 & 8.9 & 1.1 & 1.5 & 0.3 & 10 & 35.1 & 3.1 & 305.2 & 61.6 & 5 \\
\hline FLIP-97-16L & 61 & 102 & 17 & 1.3 & 1.5 & 0.5 & 28 & 44.7 & 2.3 & 531.7 & 60.5 & 5 \\
\hline ILL-10681 & 63 & 116 & 41.5 & 1.3 & 1.5 & 1.9 & 53 & 32.1 & 3.3 & 202.2 & 89.7 & 5 \\
\hline
\end{tabular}


TABLE 12: Continued.

\begin{tabular}{|c|c|c|c|c|c|c|c|c|c|c|c|c|}
\hline Genotype name & $\mathrm{DF}$ & $\mathrm{DM}$ & NP & NSS & PWPP & SWPP & NSPP & $\mathrm{PHH}$ & SW & $\mathrm{BI}$ & SY & PSS \\
\hline Chekol X R-186-2 & 61 & 110 & 46.9 & 1.4 & 1.5 & 1.6 & 62 & 38.4 & 3.1 & 345.3 & 118.8 & 5 \\
\hline FLIP-2004-37L & 63 & 109 & 32.1 & 1.9 & 1.5 & 1.3 & 50 & 29.1 & 2.5 & 181.8 & 60.1 & 5 \\
\hline FLIP-84-95L & 59 & 129 & 12.4 & 1 & 1.5 & 0.5 & 13 & 33.2 & 4.1 & 295.2 & 48.6 & 5 \\
\hline EL-142 X R-186-3 & 58 & 112 & 66 & 1.4 & 1.5 & 2.4 & 95 & 37.6 & 2.4 & 437.9 & 156.6 & 2 \\
\hline FLIP-97-61L & 63 & 129 & 44 & 1.4 & 1.5 & 2.1 & 70 & 20.6 & 3.2 & 135.4 & 46.6 & 4 \\
\hline 36134 & 55 & 90 & 33.1 & 1.2 & 1.5 & 1 & 37 & 32.7 & 2.2 & 289.2 & 108 & 5 \\
\hline GM & 57 & 96 & 35.3 & 1.2 & 1.5 & 1.1 & 43 & 34.6 & 2.5 & 286.8 & 84.9 & 5 \\
\hline SEM & 2.1 & 3.9 & 6.5 & 0.1 & 0.1 & 0.2 & 8.2 & 1.6 & 0.2 & 45.2 & 18.2 & 0.3 \\
\hline SE Difference & 3 & 5.5 & 9.2 & 0.2 & 0.2 & 0.3 & 11.6 & 2.3 & 0.3 & 64 & 25.7 & 0.4 \\
\hline LSD at $5 \%$ & 6 & 10.8 & 18.1 & 0.4 & 0.4 & 0.7 & 22.7 & 4.6 & 0.5 & 125.9 & 50.7 & 0.8 \\
\hline $\mathrm{CV} \%$ & 6.5 & 7 & 31.9 & 19.9 & 16.5 & 36.8 & 33 & 8.2 & 12.2 & 27.3 & 37.1 & 9.7 \\
\hline
\end{tabular}

$\mathrm{DF}=$ days to $50 \%$ flowering, DM = days to $90 \%$ maturity, NP = number of pods per plant, NSS = number of seeds per pod, PWPP = Pod weight per plant, SWPP = seed weight per plant, NSPP = number of seeds per plant, $\mathrm{PH}=$ plant height in $\mathrm{cm}, \mathrm{SW}=100$-seed weight in gram, $\mathrm{BI}=$ biomass, $\mathrm{SY}=$ seed yield, $\mathrm{PSS}$ = pod set score.

weight, number of seeds/plant, and biological yield/plant was high in both seasons. However, traits such as days to $50 \%$ flowering, days to $90 \%$ maturity, and plant height consistently showed lower GCV values of between $2.4 \%$ and $17 \%$. The remaining traits lack consistency and showed low to moderate GCV for number of seeds/pods, seed weight/plant, and pod weight/plant. Similar significant and considerable variation for (phenotypic and genotypic) results was reported for biological yield/plant, seed yield/plant, and 100-seed weight by $[15,35,43,45-48]$. However, as opposed to this finding, $[49,50]$ reported higher GCV and PCV for days to $50 \%$ flowering but they reported the same record for days to 90\% maturity and plant height. Similarly, [35] reported the minimum PCV and GCV for days to maturity and number of seeds/pod.

According to [51], most characters have showed high heritability estimate over locations except at Chefe Donsa due to severe wilt incidence. Reference [52] reported comparable high heritability estimates for all traits except for plant height and biological yield on lentil. Reference [15] similarly recorded high heritability for 100 -seed weight, days to $50 \%$ flowering, and days to $90 \%$ maturity. Reference [7] also reported high heritability for seed weight and days to $50 \%$ flowering. In line with our finding, [53] reported that those days to $50 \%$ flowering showed higher heritability estimates; however, they differed in reporting with higher genetic advance. 100-seed weight, rust severity score, and seed yield showed high heritability values coupled with high genetic advance values across locations because of high GCV. Numbers of seeds/plant, seed weight/plant, and number of seeds/pods have intermediate GCV and heritability with a mild response to selection. Similar to our findings, [45] reported higher degree of PCV, GCV, and genetic advance for seed yield/plant on lentil. However, in contrast to these reports, higher PCV, GCV, and genetic advance were recorded for biological yield/plant.

The GCV along with heritability estimates provide a reliable estimate of the amount of genetic advance expected through phenotypic selection [54]. Based on the underlying facts, four groups of traits were categorized as per the analysis: the first group included plant height, days to $50 \%$ flowering, and days to $90 \%$ maturity which have low GCV with a high heritability but they end up with low genetic advance. [42, 44] made a similar report that high heritability estimate for days to $50 \%$ flowering and days to $90 \%$ maturity with low genetic advance values on lentil. The second group of characters was above ground biomass, number of seeds/plant, and number of pods/plant with intermediate GCV, heritability, and genetic advance. However, deviated from our findings, studies by $[42,44,45]$ reported high heritability and expected genetic gain estimate for above ground biomass and number of pods/plant.

The third group of characters, rust severity score, seed yield, and 100-seed weight, has higher GCV with high heritability coupled with high genetic advance as percentage of the mean. Reference $[42,44]$ reported high heritability estimate for seed yield and 100-seed weight coupled with higher genetic gain. High heritability for the characters indicated that these traits were less affected by environmental factors. This is indicative of the fact that these traits are mostly controlled by genetic factors and expected to respond to direct selection for traits improvement. The fourth group of characters, pod weight/plant, seed weight/plant, and number of seeds/pods, showed inconsistent GCV, heritability, and genetic advance values across locations. These findings indicated that measuring yield components in breeding program would be difficult. From our follow-up study by (unpublished data), the second and the third groups of characters responded more to selection and the most important traits that contributed to the genetic divergence of lentil. From our follow-up association study (unpublished data), these traits attributed a strong association with seed yield. Therefore, for selecting high yielding lentil genotypes, the breeder should give emphasis to higher seed weight/plant, more number of pods/plant, and plants with short to intermediate height. This observation is in accordance with $[55,56]$ selection based on number of pods/plant and seed weight/plant which were the most important characters that contributed to 
seed yield. However, days to $90 \%$ maturity, rust disease severity score, and days to $50 \%$ flowering which otherwise had a negative phenotype correlation with seed yield had substantially negative direct effect on seed yield (unpublished data).

\section{Conclusion}

This study has described a high phenotypic diversity for important agromorphological characteristics of landraces and exotic genotypes of Ethiopia gene pool. The incidence of highly significant variation between landraces and exotic line for the majority of traits considered is a sign of the presence of a high degree of genetic variation implying the great potential of the Ethiopian germplasm in future breeding programs through selection. As per the analysis, four groups of traits were categorized. Some promising landraces were identified with superior plant characteristics, such as early flowering and early maturing accessions, wide range of genetic base for plant height, number of seeds/plant, resistance to rust, and both low and high yielding lines. Seed yield, 100-seed weight in gram, rust disease score, and total number of seeds/plant consistently showed higher GCV, heritability, and genetic advance in the lentil genotypes. All these important agromorphological characteristic traits with their associated genotypes could be successfully utilized in breeding programs that are aimed at improving the yield and the yield components of lentil. The wide genetic base that is possessed by the Ethiopian germplasm would be integrated in a breeding program and used as a parent in a recombination breeding.

In conclusion, this study has demonstrated that the exotic accessions introduced from ICARDA have a rich genetic potential for 100-seed weight, number of seeds/plant, seed weight/plant, short stature, and resistant source for rust. The Ethiopian landraces were potentials for earliness, higher number of pods/plant, and long plant height. This study has showed a high phenotypic diversity of important plant characteristics of the Ethiopian lentil germplasm. However, additional search is needed to develop a specific plant idotype for major agroecological zone to provide as a platform for local adaptation and then breed for location relevant traits, such as a biotic stresses and identification source of resistance for other major important diseases.

\section{Conflict of Interests}

The authors declare that they have no conflict of interests regarding the publication of this paper.

\section{Acknowledgments}

The authors are most grateful for Gonder University, Haramaya University, Federal Ministry of Education, ICARDA Legume Research Program, ICARDA Ethiopia country office, Ethiopian Institute of Agricultural Research Center, National Chickpea and Lentil Research Project in Debrezeit Agricultural Research Center, Sirinka Agricultural Research Center and Sinana Agricultural Research Center, and Institute Biodiversity Conservation, for research funding supports of this study.

\section{References}

[1] D. Zohary, "The wild progenitor and the place of origin of the cultivated lentil:Lens culinaris," Economic Botany, vol. 26, no. 4, pp. 326-332, 1972.

[2] H. Barulina, "Lentils of the USSR and other countries," in Bulletin of Applied Botany, Genetics and Plant Breeding Supplement, pp. 265-304, USSR Institute of Plant Industry of the Lenin Academy of Agricultural Science Leningrad, USSR, 1930.

[3] W. Erskine, "Global production, supply and demand," in The Lentil: Botany, Production and Uses, F. J. William Erskine, Muehlbauer, A. Sarker, and B. Sharma, Eds., pp. 4-12, CABI, London, UK, 2009.

[4] FAOSTAT, "Distribution of global lentil production among India, Canada and Turkey (the "big three" producers) and by continent," FAOSTAT, 2009, http://faostat.fao.org/.

[5] G. Bejiga, S. Tsegaye, and A. Tullu, "Stability of seed yield for some varieties of lentil grown in the Ethiopian highlands," Crop Research, vol. 9, pp. 337-343, 1995.

[6] CSA, Central Statistical Agency Agricultural Sample Survey Report on: Area and Production of Crops, Statistical Bulletin, Addis Ababa, Ethiopia, 2012.

[7] G. Bejiga, S. Tsegaye, A. Tullu, and W. Erskine, "Quantitave evaluation of Ethiopian landraces of lentil (Lens culinaris)," Genetic Resources and Crop Evolution, vol. 43, no. 4, pp. 293301, 1996.

[8] F. Asnake and G. Bejiga, "Breeding lentil for wider adaptation," in Forage and Food Legumes of Ethiopia: Progress and Prospects. Proceedings of the Workshop on Food and Forage Legumes, A. Kemal, K. Gemechu, A. Seid et al., Eds., pp. 80-86, EIAR and ICARDA. International Center for Agricultural Research in the Dry Areas (ICARDA), Aleppo Syria, Addis Ababa, Ethiopia, September 2003.

[9] R. W. Allard, Principles of Plant Breeding, John Wiley \& Sons, New York, NY, USA, 1960.

[10] W. Erskine, Y. Adham, and L. Holly, "Geographic distribution of variation in quantitative traits in a world lentil collection," Euphytica, vol. 43, no. 1-2, pp. 97-103, 1989.

[11] M. Ahmad, D. L. McNeil, and J. R. Sedcole, "Phylogenetic relationships in Lens species and their interspecific hybrids as measured by morphological characters," Euphytica, vol. 94, no. 1, pp. 101-111, 1997.

[12] J. S. C. Smith and O. S. Smith, "The description and assessment of distance between inbred lines of maize. The use of morphological traits as descriptors," Maydica, vol. 34, pp. 141-150, 1989.

[13] K. Mather and J. L. Jinks, Biometrical Genetics: The Study of Continuous Variation, Chapman and Hall, London, UK, 2nd edition, 1971.

[14] H. W. Johnson, H. F. Robinson, and R. E. Comstock, "Estimate of genetic and environmental variability in soybeans," Agronomy Journal, vol. 47, pp. 314-318, 1955.

[15] B. T. Bicer and D. Sakar, "Genetic variability and heritability for grain yield and other characters in lentil," Journal Biological Science, vol. 4, pp. 216-218, 2004.

[16] B. T. Bicer and D. Sakar, "Stability parameters in lentil," Journal of Central European Agriculture, vol. 7, pp. 439-443, 2006. 
[17] W. Erskine, P. C. Williams, and H. Nakkoul, "Genetic and environmental variation in the seed size, protein, yield, and cooking quality of lentils," Field Crops Research, vol. 12, pp. 153161, 1985.

[18] A. Tullu, I. Kusmenoglu, K. E. Mcphee, and F. J. Muehlbauer, "Characterization of core collection of lentil germplasm for phenology, morphology, seed and straw yields," Genetic Resources and Crop Evolution, vol. 48, no. 2, pp. 143-151, 2001.

[19] A. Sarker and W. Erskine, "Recent progress in the ancient lentil," Journal of Agricultural Science, vol. 144, no. 1, pp. 19-29, 2006.

[20] S. Roy, M. A. Islam, A. Sarker, M. A. Malek, M. Y. Rafii, and M. R. Ismail, "Determination of genetic diversity in lentil germplasm based on quantitative traits," Australia Journal of Crop Science, vol. 7, pp. 14-21, 2013.

[21] F. Edossa, T. Kassahun, and B. Endashaw, "A comparative study of morphological and molecular diversity in Ethiopian lentil (Lens culinaris Medikus) landraces," African Journal of Plant Science, vol. 4, pp. 242-254, 2010.

[22] T. Seifu, Correlation and path coefficient analysis in lentil (Lens culinaries Medik.) and their implication for selection [M.S. thesis], Alemaya Agricultural University, Addis Ababa, Ethiopia, 1988.

[23] B. Geletu and A. Yadeta, "Genetic and breeding research in lentil," in Cool-Season Food Legumes of Ethiopia. Proceedings of the 1st National Cool-Season Food Legumes Review Conference, December 1993, A. Telaye, G. Bejiga, M. C. Saxena, and M. Solh, Eds., pp. 6416-8420, Addis AbabaInstitute of Agricultural Research. ICARDA, Aleppo, Syria, 1994.

[24] D. Tigist, Genetic variability and associations among yield and yield related characters in exotic lentil lines (Lens culinaries Medik.) [M.S. thesis], Alemaya University, East Harerge, Ethiopia, 2003.

[25] D. Ketema, Genetic Variation for Agronomic and Root Characters in Ethiopian Lentil (Lens culinaris Medikus) Landraces Grown Under Moisture Stress [M.S. thesis], Haramaya University, East Harerge, Ethiopia, 2007.

[26] W. Chen, Stemphylium Blight Disease Scoring in Field Condition, USDA-ARS, Washington State University, Pullman Wash, USA, 2007.

[27] VSN International, GenStat for Windows, VSN International, Hemel Hempstead, UK, 13th edition, 2010.

[28] W. T. Federer, "Augmented designs with one-way elimination of heterogeneity," Biometrics, vol. 17, pp. 447-473, 1961.

[29] C. S. Lin, M. R. Binns, and L. P. Lefkovitch, "Stability analysis: where do we stand?" Crop Science, vol. 26, pp. 894-900, 1986.

[30] S. K. Yau and J. Hamblin, "Relative yield as a measure of entry performance in variable environments," Crop Science, vol. 34, no. 3, pp. 813-817, 1994.

[31] VSN International, GenStat for Windows, VSN International, Hemel Hempstead, UK, 15th edition, 2012.

[32] H. A. Al-Jibouri, P. A. Miller, and H. F. Miller, "Genotypic and environmental variances and co variances in an upland cross of inter specific origin," Agronomy Journal, vol. 50, pp. 633-636, 1958.

[33] S. N. Deshmukh and P. S. Reddy, "Genetic variability, character association and path coefficients of quantitative traits in Virginia bunch varieties of ground nut," Indian Journal Agricultural Science, vol. 56, pp. 816-821, 1986.

[34] S. C. Agrawal, M. N. Khare, and P. S. Agrawal, "Field screening of lentil lines for resistance to rust," Indian Journal of Phytopathology, vol. 292, pp. 20-28, 1976.
[35] M. Chakrabotry and M. F. Haque, "Genetic variability and component analysis in lentil (Lens culinaris Medik.)," Journal Lentil Research, vol. 12, pp. 199-204, 2000.

[36] B. T. Bicer and D. Sakar, "Studies on variability of lentil genotypes in Southeastern Anatolia of Turkey," Notulae Botanicae Horti Agrobotanici Cluj-Napoca, vol. 36, pp. 20-24, 2008.

[37] F. Toklu, B. Tuba Biçer, and T. Karaköy, "Agro-morphological characterization of the Turkish lentil landraces," African Journal of Biotechnology, vol. 8, no. 17, pp. 4121-4127, 2009.

[38] T. Sultana, S. Nadeem, Z. Fatima, and A. Ghafoor, "Identification of elite pure-lines from local lentil germplasm using diversity index based on quantitative traits," Pakistan Journal of Botany, vol. 42, no. 4, pp. 2249-2256, 2010.

[39] A. L. A. Al-Ghzawi, E. Bsoul, F. Aukour, Z. Al-Ajlouni, M. AlAzzam, and M. M. Ajlouni, "Genetic variation for quantitative traits in Jordanian lentil landraces," Advances in Environmental Biology, vol. 5, no. 11, pp. 3676-3680, 2011.

[40] K. B. Singh and S. Singh, "Evaluation of exotic germplasm in lentil," Journal Agricultural Research, vol. 6, pp. 304-306, 1991.

[41] M. Solh and W. Erskine, "Genetic resources of lentils," in Genetic Resources and Their Exploitation Chickpeas, Faba Beans and Lentils, J. R. Witcombe and W. Erskine, Eds., pp. 205-217, Martinus Nijhoff, The Hague, The Netherlands, 1984..

[42] B. N. Baidya, A. M. Eunus, and S. Sen, "Estimation of variability and correlation in yield and yield contributing characters in lentil (Lens culinaris)," Environmental Ecology, vol. 6, pp. 694697, 1988.

[43] A. S. Rathi, J. S. Sindhu, and V. S. Singh, "Variability, heritability and genetic advance in lentil," Legume Research, vol. 25, pp. 113$116,2002$.

[44] O. Vir, V. P. Gupta, and O. Vir, "Variation in Macrosperma x microsperma derived gene pool of lentil under low and high fertility levels of soil at sub-tropical climate of Himalayas," Indian Journal Agricultural Research, vol. 32, pp. 181-184, 1998.

[45] N. Kishore and V. P. Gupta, "Early generation selection in microsperma and macrosperma derived gene pool of lentil," Indian Journal Genetics and Plant Breeding, vol. 62, pp. 34-37, 2002.

[46] N. I. Haddad, T. P. Bogyo, and F. J. Muehlbauer, "Genetic variance of six agronomic characters in three lentil (Lens culinarisMedic) crosses," Euphytica, vol. 31, no. 1, pp. 113-120, 1982.

[47] M. Singh, A. Sarker, and W. Erskine, "Estimation of heritability using spatial variability models: the case of lentil (Lens culinaris Medik.)," Indian Journal Genetics and Plant Breeding, vol. 65, pp. 77-83, 2005.

[48] S. D. Tyagi and M. H. Khan, "Correlation, path-coefficient and genetic diversity in lentil (Lens culinaris Medik) under rainfed conditions," International Research Journal of Plant Science, vol. 2, pp. 191-200, 2011.

[49] S. Ayaz, B. A. McKenzie, G. D. Hill, and D. L. McNeil, "Variability in yield of four grain legume species in a subhumid temperate environment. II. Yield components," Journal of Agricultural Science, vol. 142, no. 1, pp. 21-28, 2004.

[50] G. Singh, I. S. Singh, and R. Kumar, "Genetic variability for seed yield and its component characters in a macrosperma $\times$ microsperma cross of lentil (Lens culinaris Medik.)," Crop Improvement, vol. 31, pp. 206-209, 2004.

[51] H. F. Robinson, R. E. Comstock, and P. H. Harvey, "Genetic and phenotypic correlation in corn and their implications in selection," Agronomy Journal, vol. 43, pp. 283-287, 1954. 
[52] S. K. Jain, S. K. Madaria, S. K. Rao, and P. K. Nigam, "Analysis of yield factors in lentil," Indian Journal of Agricultural Research, vol. 29, pp. 173-180, 1995.

[53] M. Singh, D. K. Maheshwari, R. K. Mittal, S. K. Sharma, and M. Singh, "Genetic variability and correlation of grain yield and other quantitative characters in lentil (Lens culinaris Medik)," Annals Agricultural Biological Research, vol. 4, pp. 121-124, 1999.

[54] G. W. Burton and E. H. DeVane, "Estimation heritability in Tall Festuca (Festuca arundinacea) from replicated clonal material," Agronomy Journal, vol. 45, pp. 478-481, 1953.

[55] S. A. M. Khattab, "Association and Path analysis in lentil under different irrigation regimes," Egypt Journal Agronomy, vol. 20, pp. 13-25, 1999.

[56] S. Sarvjeet, I. Singh, R. K. Gill, L. Kaur, and A. Sarker, "Evaluation of exotic lentil germplasm and studies on genetic parameters for various traits," Journal of Lentil Research, vol. 3, pp. 2227, 2006. 


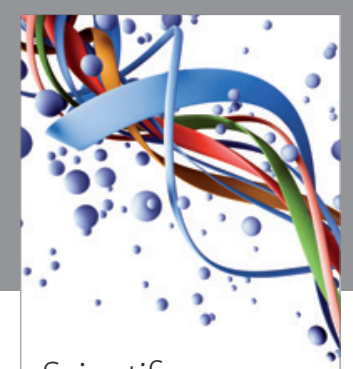

Scientifica
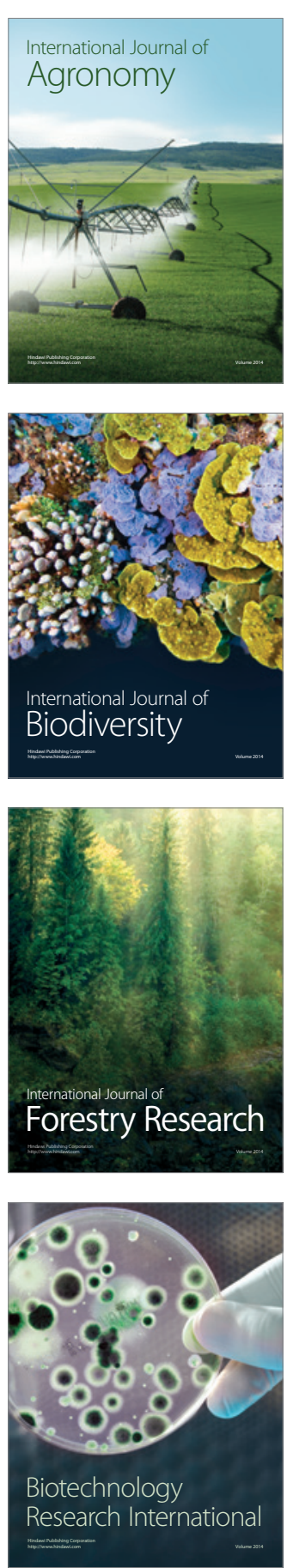
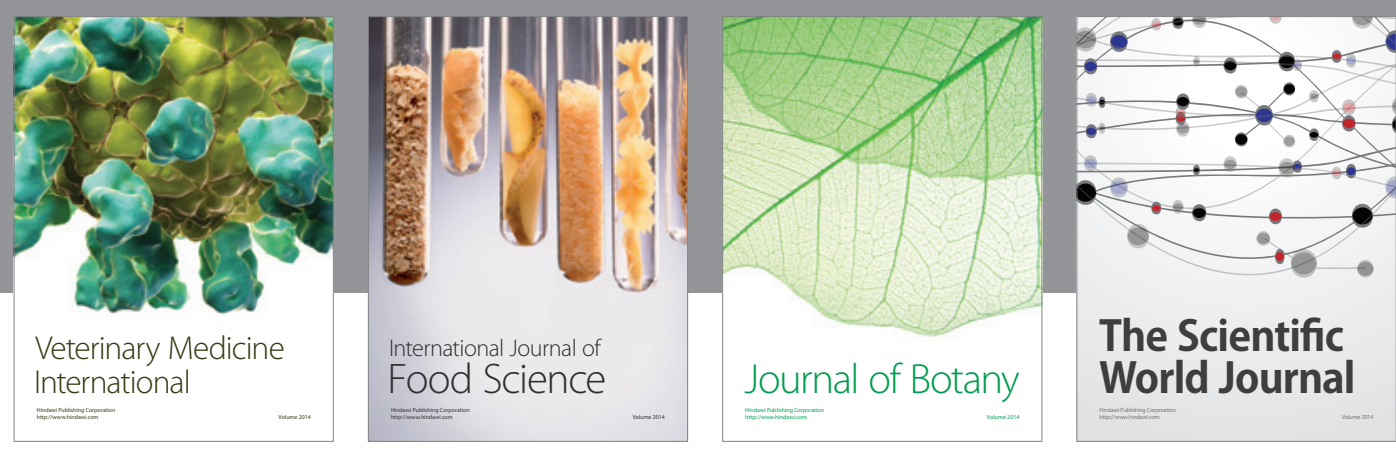

The Scientific World Journal
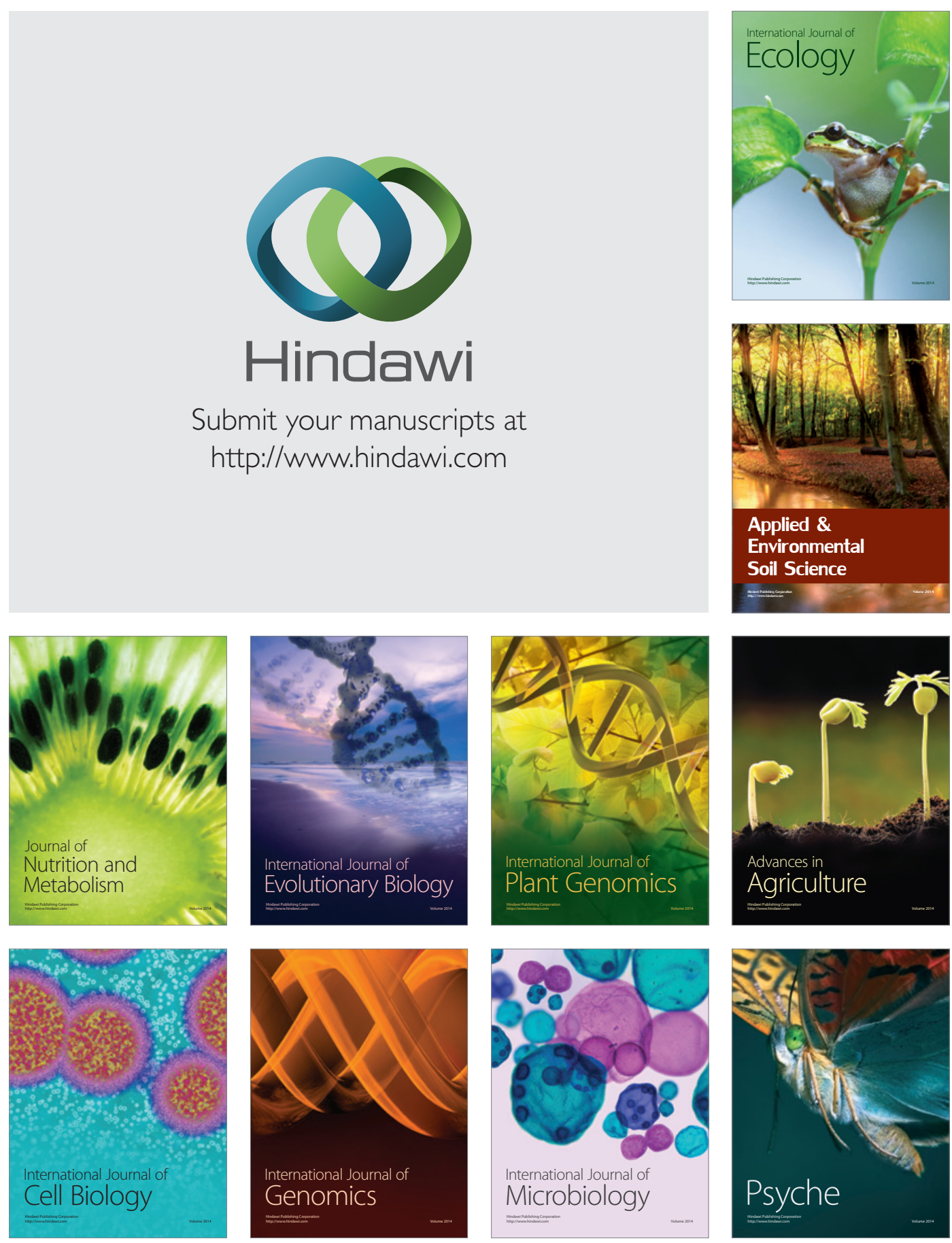